\title{
Electron Capture Dissociation \\ and Infrared Multiphoton Dissociation of Oligodeoxynucleotide Dications
}

\author{
Kristina Håkansson, Robert R. Hudgins, and Alan G. Marshall* \\ Ion Cyclotron Resonance Program, National High Magnetic Field Laboratory, Tallahassee, Florida, USA
}

Richard A. J. O'Hair

School of Chemistry, University of Melbourne, Victoria, Australia

We report electron capture dissociation (ECD) and infrared multiphoton dissociation (IRMPD) of doubly protonated and protonated/alkali metal ionized oligodeoxynucleotides. Mass spectra following ECD of the homodeoxynucleotides polydC, polydG, and polydA contain $w$ or $d$ "sequence" ions. For polydC and polydA, the observed fragments are even-electron ions, whereas radical $w / d$ ions are observed for polydG. Base loss is seen for polydG and polydA but is a minor fragmentation pathway in ECD of polydC. We also observe fragment ions corresponding to $w / d$ plus water in the spectra of polydC and $\mathrm{d}$ (GCATGC). Although the structure of these ions is not clear, they are suggested to proceed through a pentavalent phosphorane intermediate. The major fragment in ECD of d(GCATGC) is a $d$ ion. Radical $a$ - or $z$-type fragment ions are observed in most cases. IRMPD primarily results in base loss, but backbone fragmentation is also observed. IRMPD provides more sequence information than ECD, but the spectra are more complex due to extensive base and water losses. It is proposed that the smaller degree of sequence coverage in ECD, with fragmentation mostly occurring close to the ends of the molecules, is a consequence of a mechanism in which the electron is captured at a $\mathrm{P}=\mathrm{O}$ bond, resulting in a negatively charged phosphate group. Consequently, at least two protons (or alkali metal cations) must be present to observe a $w$ or $d$ fragment ion, a requirement that is less likely for small fragments. (J Am Soc Mass Spectrom 2003, 14, 23-41) (C) 2003 American Society for Mass Spectrometry

A major aim in biological mass spectrometry has been the development of techniques to sequence peptides, proteins [1] and fragments of DNA [2-4]. A biomolecule sequence is generally obtained by tandem mass spectrometry (MS/MS) [5], in which a parent ion is first isolated from other ions of different mass-to-charge $(\mathrm{m} / \mathrm{z})$ ratio and then dissociated into sequence-specific fragment ions. The fragmentation technique (e.g., collision induced dissociation (CID) [6], infrared multiphoton dissociation (IRMPD) $[7,8]$, blackbody infrared radiative dissociation (BIRD) $[9,10]$, surface induced dissociation (SID) [11], or ultraviolet photodissociation $[12,13])$ as well as the nature of the parent ion charge (singly versus multiply charged, protonation versus metal cation attachment, cation ver-

Published online November 28, 2002

Address reprint requests to Dr. A. G. Marshall, Ion Cyclotron Resonance Program, National High Magnetic Field Laboratory, Florida State University, 1800 E. Paul Dirac Drive, Tallahassee, FL 32310, USA. E-mail: marshall@magnet.fsu.edu or Dr. R. A. J. O'Hair, School of Chemistry, University of Melbourne, Victoria 3010, Australia.

*Also a member of the Department of Chemistry and Biochemistry, Florida State University, Tallahassee, FL 32306. sus anion, etc.) play key roles in determining the major fragmentation processes.

To date most attention has focused on the fragmentation reactions of even-electron ions, but electrospray ionization in combination with ion-ion reactions, ionelectron reactions, or ion-neutral reactions have opened up new opportunities to examine the fragmentation reactions of odd-electron ions. Examples include electron capture dissociation (ECD) of $[\mathrm{M}+\mathrm{nH}]^{\mathrm{n}+}$ ions of peptides and proteins [14, 15], polymers [16, 17], and peptide nucleic acids (PNA's) [18]; electron impact ionization of $[\mathrm{M}+\mathrm{nH}]^{\mathrm{n}+}$ and $[\mathrm{M}-2 \mathrm{H}]^{2-}$ ions of peptides [19-21]; ion-ion reactions between cations and $[\mathrm{M}-\mathrm{nH}]^{\mathrm{n}-}$ ions of oligodeoxynucleotides [22, 23]; high-energy collisional electron transfer from $[\mathrm{M}+$ $\mathrm{nH}]^{\mathrm{n}+}$ and $[\mathrm{M}-\mathrm{H}]^{-}$ions of peptides to dioxygen [24], and $\mathrm{CID}$ of a $\mathrm{Cu}(\mathrm{II})$-amine-peptide complex [25]. In each case, the formation of the radical cation (or anion) results in new fragmentation pathways, which are complementary to those observed for even-electron fragmentation. For example, disulfide bond cleavage is observed as a major fragmentation pathway in ECD [26], whereas such cleavage is not observed in CID or IRMPD. In other instances, novel fragmentation chem- 
istry has been exploited to examine posttranslational modifications in peptides and proteins by ECD [27-31]. Moreover, fragmentation of radical peptide ions allows distinction of the isomeric amino acid residues, leucine and isoleucine, through characteristic side-chain cleavages [32, 33].

Because electron transfer processes and radical reactions play important roles in the damage of DNA [34-36], it is of interest to examine the ECD reactions of oligodeoxynucleotides. For example, it has recently been demonstrated that low-energy (3-20 eV) electrons cause both single- and double strand breaks in DNA solids under UHV conditions [37]. Most previous work on gas-phase fragmentation reactions of oligonucleotides has been directed at multiply deprotonated anions [38-47], except for some CID of protonated species produced by fast atom bombardment [48] or electrospray ionization (ESI) [49-53], and post-source decay (PSD) of ions produced by matrix-assisted laser desorption/ionization (MALDI) [54]. For negatively-charged even-electron precursor ions, Gross and co-workers found that different modes of ionization (ESI versus MALDI) and ion activation (low-energy CID versus high-energy CID) gave similar fragmentation patterns [43]. In the same paper, it was suggested that fragmentation of even-electron oligonucleotide anions is driven by nucleobase protonation through proton transfer from the phosphate backbone, leading to a zwitterion intermediate. Fragmentation is thus site-specific and depends on the proton affinities of the nucleobases. That hypothesis was later confirmed by MALDI PSD [44] and ESI CID [45] in combination with hydrogen/ deuterium exchange, by fragmentation of oligodeoxynucleotides adducted to metal ions [46], and by replacing phosphates with methylphosphonates [47]. Fragmentation of positively-charged even-electron precursor ions has also been found to result from nucleobase protonation followed by base loss and further backbone cleavages [54]. A unique fragmentation of adenine-containing oligonucleotides was explained by interaction between the adenine base and the phosphate backbone, lowering the proton affinity of the base. Here, we present ECD results for doubly protonated and protonated/cationized homodeoxynucleotides, $\mathrm{dC}_{4}-\mathrm{dC}_{7}, \mathrm{dG}_{5}, \mathrm{dG}_{7}$, and $\mathrm{dA}_{6}$, as well as $\mathrm{d}(\mathrm{GCATGC})$, which contains all four kinds of nucleotides. We chose to investigate both protonated and protonated/cationized oligonucleotides because we had observed earlier that such precursor ions fragment very differently in ECD of O-glycosylated peptides [55]. We also compare the ECD fragmentation patterns to the ones resulting from IRMPD of the corresponding even-electron ions.

\section{Methods}

\section{Sample Preparation}

All oligodeoxynucleotides were purchased from TriLink BioTechnologies, Inc. (San Diego, CA) as their crude ammonium salts and were used without further purification. The lyophilized samples were dissolved in HPLC grade water (J. T. Baker, Philipsburg, NJ) to a concentration of $\sim 1 \mathrm{mM}$.

\section{Electron Capture Dissociation}

ECD was performed on a homebuilt, unshielded, 7 tesla FT-ICR mass spectrometer [56] equipped with a heatedfilament electron gun located behind the ICR cell [57]. The oligonucleotide stock solutions were diluted tenfold (i.e., to $10^{-4} \mathrm{M}$ ) into an electrospray solvent consisting of $1: 1$ methanol:water with $0.1-0.5 \%$ formic acid. An electrospray emitter consisting of a $50 \mu \mathrm{m}$ i.d. fused silica capillary, which had been mechanically ground to a uniform thin-walled tip [58] was used to infuse the oligonucleotides at a flow rate of $300 \mathrm{~nL} / \mathrm{min}$. The emitter was operated in the positive ion mode. Ions were externally accumulated in an octopole pretrap [59] for 1.5 to $8 \mathrm{~s}$. After accumulation, the ions were transferred through a hexapole ion guide $(0.9$ to $1.5 \mathrm{~ms}$ transfer time depending on the $m / z$ value) and captured by gated trapping in an open orthorhombic cell. Storedwaveform inverse Fourier transform (SWIFT) [60, 61] ejection was applied in two stages to isolate the oligonucleotide under investigation: first, a broadband SWIFT with an 80 Da wide notch centered around the oligonucleotide ion, and second, a narrowband SWIFT within the $80 \mathrm{Da}$ window. The isolated parent ions were irradiated with electrons for $30 \mathrm{~s}$. A filament bias voltage of $3.1 \mathrm{~V}$ and a heating current of $3.8 \mathrm{~A}$, resulting in a voltage drop of $4.3 \mathrm{~V}$ across the filament, was used. A voltage $(-2 \mathrm{~V})$ was applied to a repeller plate located behind the filament [57]. The ECD fragment ions were subjected to chirp excitation $(43 \mathrm{kHz}$ to $1 \mathrm{MHz}$ at 350 $\mathrm{Hz} / \mu \mathrm{s})$ and direct-mode broadband detection (512 Kword data points). Hanning apodization and one zero-fill were applied prior to fast Fourier transform followed by magnitude calculation. Frequency-to- $m / z$ conversion was performed with the usual two-term calibration equation $[62,63]$. The experimental event sequence was controlled by an Odyssey data acquisition system (FinniganThermoQuest Corp., Bremen, Germany). Each displayed spectrum represents a sum of 50 time-domain transients.

\section{Infrared Multiphoton Dissociation}

The ECD electron gun can be moved off-axis from its preferred central position to allow infrared photons to enter the ICR cell on-axis for IRMPD. A $40 \mathrm{~W}, 10.6 \mu \mathrm{m}$, $\mathrm{CO}_{2}$ laser (Synrad, Mukilteo, WA) provided the photons. The laser beam is directed to the center of the cell through a $\mathrm{BaF}_{2}$ window. No optics were used to focus the beam. Photon irradiation was performed for 25 to $250 \mathrm{~ms}$ at 5\% laser power. 


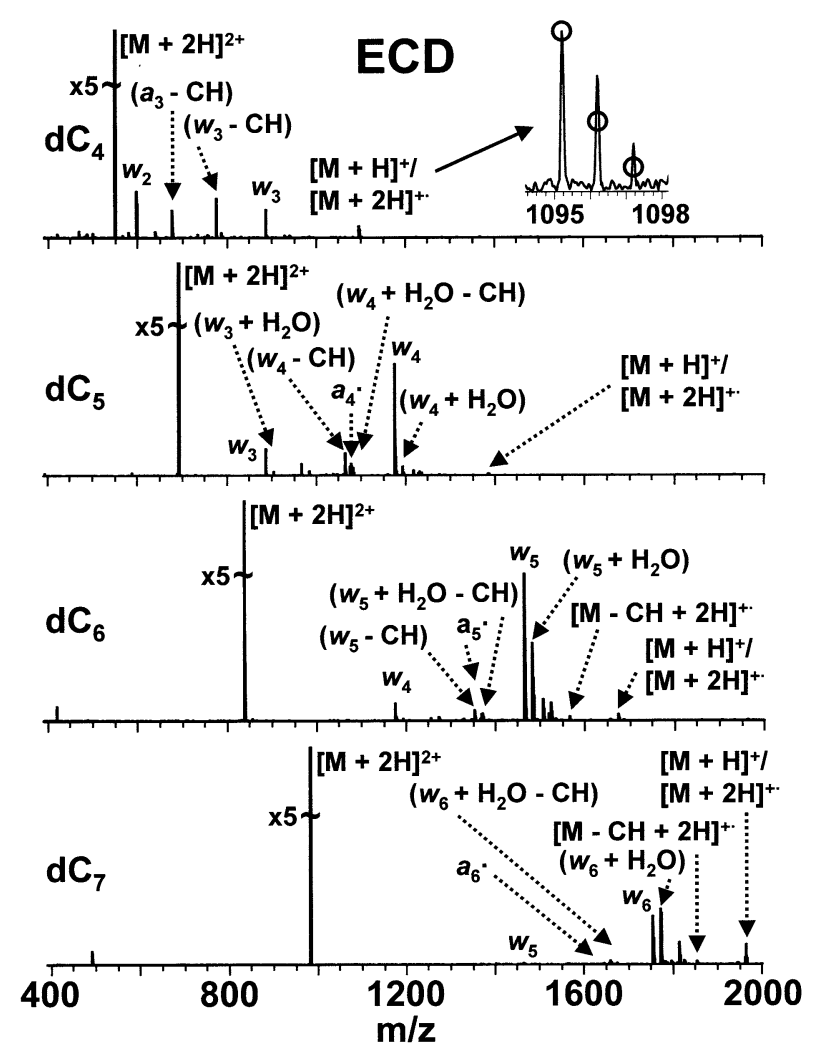

Figure 1. FT-ICR mass spectra following ECD of doubly protonated polydeoxycytidine (50 summed scans, $30 \mathrm{~s}$ irradiation each). All spectra contain two consecutive even-electron "sequence" ions, labeled $w_{\mathrm{n}}$. These ions could also be $d$-type fragment ions (see text). One radical "sequence" ion (labeled $a_{n}{ }^{*}$ ) is seen in the spectra of $\mathrm{dC}_{5}-\mathrm{dC}_{7}$, respectively. Cytosine neutral base $(\mathrm{CH})$ loss is observed from the $w / d$ ions and, to a low degree, from the reduced parent ions. The structure of the $\left(w_{n}+\mathrm{H}_{2} \mathrm{O}\right) /\left(d_{n}+\mathrm{H}_{2} \mathrm{O}\right)$ ions is not clear, but they are proposed to result from gas-phase hydrogen bonding between a phosphate oxygen and a free hydroxyl group of a 5'- or 3'-terminal sugar residue. For $\mathrm{dC}_{4}$, the inset shows the isotopic distribution of the charge-reduced parent ion. The deviation from the theoretical $[\mathrm{M}+\mathrm{H}]^{+}$distribution (open circles) indicates the presence of both $[\mathrm{M}+\mathrm{H}]^{+}$and $[\mathrm{M}+2 \mathrm{H}]^{+}$.

\section{Results and Discussion}

\section{ECD of Doubly Protonated Polydeoxycytidine}

The ionic products of ECD of doubly protonated $\mathrm{dC}_{4}$, $\mathrm{dC}_{5}, \mathrm{dC}_{6}$, and $\mathrm{dC}_{7}$ are shown in Figure 1 and the major fragments are listed in Table 1. In all spectra, the isotopic distribution of the singly charged non-fragmented ion resulting from electron capture by the doubly protonated parent ion shows the presence of two species: The radical ion $[\mathrm{M}+2 \mathrm{H}]^{+\cdot}$ and the even-electron ion $[\mathrm{M}+\mathrm{H}]^{+}$. The $[\mathrm{M}+\mathrm{H}]^{+}$ion is most likely a result of hydrogen atom $(\mathrm{H} \cdot)$ ejection from $[\mathrm{M}+$ $2 \mathrm{H}]^{+}$. In all polydC spectra, two of the major fragment ions can be identified as consecutive backbone "sequence" ions, of either the $w$ - or $d$-type [38,52]. It is not possible to distinguish between those two ion types based on mass alone because of the symmetry of polydC (i.e., the nucleotide sequence is identical when read from the 5 ' or $3^{\prime}$ end). The observed $w / d$ ions are even-electron species.

\section{Pathways and Mechanisms for ECD Cleavage of DNA}

Possible dissociation mechanisms are shown in Scheme 1, paths (a) and (b). The complementary $a / z$ ions are radical ions. Such $a \cdot / z \cdot$ ions are observed at low abundance in the mass spectra following ECD of $\mathrm{dC}_{5}-\mathrm{dC}_{7}$. Their lower abundance may be attributed to the lower stability of radical ions, in analogy with the previous observation that the abundance of $z$ ions is typically about half of that of even-electron $c$ ions in ECD of peptides [28].

The mechanism shown in Scheme 1 depicts electron capture at the $\mathrm{P}=\mathrm{O}$ bond. We do not show the sites of the charges (which are most likely at the nucleobases), because this reaction does not appear to be directed by the charge (see below). Phosphorus-centered radicals produced by dissociative electron capture have previously been observed by electron paramagnetic resonance (EPR) in irradiated crystalline phosphated sugars, both at $77 \mathrm{~K} \mathrm{[64-66]} \mathrm{and} \mathrm{at} \mathrm{room} \mathrm{temperature} \mathrm{[67,}$ 68]. Scission of the phosphate-ester bond upon irradiation has also been seen for deoxycytidine 5'-phosphate $[69,70]$, although no phosphorus-centered radicals were detected in that case. The generally accepted view is that ionizing irradiation of nucleic acids primarily produces radicals centered on the nucleobases, although sugar-centered radicals have also been detected in DNA at lower yield [71]. Steenken and Goldbergerova have recently suggested that phosphate radicals are not observed in irradiated DNA because of rapid intramolecular hydrogen atom transfer from the sugar to the initially formed phosphate radical [72].

The predominant fragmentation pathway in CID of protonated oligodeoxynucleotides is the loss of a neutral base, BH [48-53]. Facile base loss (as a radical base, B., i.e., loss of mass 150 for guanine) has also been seen for the reduced species in ECD of PNA's [18]. In contrast, base loss from the reduced parent ion is observed only as a minor product in ECD of polydC. For $\mathrm{dC}_{4}$, the isotopic distribution corresponding to base loss from the reduced parent ion shows the presence of both $\left([\mathrm{M}+2 \mathrm{H}]^{+\cdot}-\mathrm{CH}\right)$ and $\left([\mathrm{M}+\mathrm{H}]^{+}-\mathrm{CH}\right)$, in which $\mathrm{CH}$ denotes a neutral cytosine base [73] (mass 111.0432). For $\mathrm{dC}_{6}$ and $\mathrm{dC}_{7}$, the corresponding distributions show the presence of $\left([\mathrm{M}+2 \mathrm{H}]^{+\cdot}-\mathrm{CH}\right)$ and $\left([\mathrm{M}+2 \mathrm{H}]^{+\cdot}-\mathrm{C}^{\cdot}\right)$, in which $\mathrm{C} \cdot$ is a radical cytosine base of mass, 110.0354. No base loss from the reduced parent ion was seen from ECD of $\mathrm{dC}_{5}$.

In addition to base loss from the reduced parent ion, we observe fragments corresponding to cleavage of both a backbone bond and a sugar-base glycosidic bond, (even-electron ions, labeled $\left[w_{\mathrm{n}}-\mathrm{CH}\right)$ ). Base loss from the fragment ions has previously been observed for ECD of PNA's [18], but the losses were seen only 
Table 1. Major fragment ions observed in ECD spectra of doubly protonated $\mathrm{dC}_{4}, \mathrm{dC}_{5}, \mathrm{dC}_{6}$, and $\mathrm{dC}_{7}$. Ions labeled $w$ can also be $d$ ions, and ions labeled $a$ can also be $z$ ions. All spectra were internally calibrated

\begin{tabular}{|c|c|c|c|c|}
\hline Sample & Observed $\mathrm{m} / \mathrm{z}$ & Calculated $\mathrm{m} / \mathrm{z}$ & Assignment & Error (ppm) \\
\hline \multirow[t]{7}{*}{$\mathrm{dC}_{4}$} & 548.1221 & 548.1221 & {$[\mathrm{M}+2 \mathrm{H}]^{2+}$} & calibrant \\
\hline & 597.1106 & 597.1106 & $w_{2}$ & 0.02 \\
\hline & 677.1372 & 677.1368 & $\left(a_{3}-\mathrm{CH}\right)$ & 0.6 \\
\hline & 775.1139 & 775.1137 & $\left(w_{3}-\mathrm{CH}\right)$ & 0.3 \\
\hline & 886.1567 & 886.1569 & $w_{3}$ & -0.2 \\
\hline & 984.1956 & 984.1938 & {$[\mathrm{M}-\mathrm{CH}+\mathrm{H}]^{+}$} & 1.9 \\
\hline & 1095.237 & 1095.237 & {$[\mathrm{M}+\mathrm{H}]^{+}$} & calibrant \\
\hline \multirow[t]{13}{*}{$\mathrm{dC}_{5}$} & 692.6453 & 692.6453 & {$[\mathrm{M}+2 \mathrm{H}]^{2+}$} & calibrant \\
\hline & 886.1600 & 886.1569 & $w_{3}$ & 3.5 \\
\hline & 904.1687 & 904.1675 & $\left(w_{3}+\mathrm{H}_{2} \mathrm{O}\right)$ & 1.3 \\
\hline & 966.1254 & & & \\
\hline & 984.1376 & & & \\
\hline & 1064.164 & 1064.160 & $\left(w_{4}-\mathrm{CH}\right)$ & 3.3 \\
\hline & 1076.219 & & & \\
\hline & 1078.232 & 1078.234 & $a_{4}$ & -2.0 \\
\hline & 1082.175 & 1082.171 & $\left(w_{4}+\mathrm{H}_{2} \mathrm{O}-\mathrm{CH}\right)$ & 4.3 \\
\hline & 1175.209 & 1175.203 & $w_{4}$ & 4.8 \\
\hline & 1193.214 & 1193.214 & $\left(w_{4}+\mathrm{H}_{2} \mathrm{O}\right)$ & 0.08 \\
\hline & 1217.210 & & & \\
\hline & 1384.283 & 1384.283 & {$[\mathrm{M}+\mathrm{H}]^{+}$} & calibrant \\
\hline \multirow[t]{14}{*}{$\mathrm{dC}_{6}$} & 837.1685 & 837.1685 & {$[\mathrm{M}+2 \mathrm{H}]^{2+}$} & calibrant \\
\hline & 1175.206 & 1175.203 & $w_{4}$ & 2.5 \\
\hline & 1255.165 & & & \\
\hline & 1353.205 & 1353.206 & $\left(w_{5}-\mathrm{CH}\right)$ & -0.8 \\
\hline & 1367.274 & 1367.281 & $a_{5}$ & -4.8 \\
\hline & 1371.220 & 1371.217 & $\left(w_{5}+\mathrm{H}_{2} \mathrm{O}-\mathrm{CH}\right)$ & 1.9 \\
\hline & 1464.252 & 1464.250 & $w_{5}$ & 1.8 \\
\hline & 1482.262 & 1482.260 & $\left(w_{5}+\mathrm{H}_{2} \mathrm{O}\right)$ & 1.4 \\
\hline & 1506.264 & & & \\
\hline & 1519.266 & & & \\
\hline & 1524.273 & & & \\
\hline & 1563.291 & 1563.294 & {$[\mathrm{M}-\mathrm{CH}+2 \mathrm{H}]^{+\cdot}$} & -2.2 \\
\hline & 1564.299 & 1564.302 & {$\left[\mathrm{M}-\mathrm{C}^{\cdot}+2 \mathrm{H}\right]^{+}$} & -1.7 \\
\hline & 1673.330 & 1673.330 & {$[\mathrm{M}+\mathrm{H}]^{+}$} & calibrant \\
\hline \multirow[t]{14}{*}{$\mathrm{dC}_{7}$} & 981.6917 & 981.6917 & {$[\mathrm{M}+2 \mathrm{H}]^{2+}$} & calibrant \\
\hline & 1464.248 & 1464.250 & $w_{5}$ & -1.1 \\
\hline & 1656.331 & 1656.327 & $a_{6}$ & 2.4 \\
\hline & 1660.262 & 1660.263 & $\left(w_{6}+\mathrm{H}_{2} \mathrm{O}-\mathrm{CH}\right)$ & 0.9 \\
\hline & 1753.296 & 1753.296 & $w_{6}$ & 0.04 \\
\hline & 1771.311 & 1771.307 & $\left(w_{6}+\mathrm{H}_{2} \mathrm{O}\right)$ & 2.4 \\
\hline & 1781.327 & & & \\
\hline & 1795.300 & & & \\
\hline & 1813.322 & & & \\
\hline & 1824.349 & & & \\
\hline & 1852.348 & 1852.341 & {$[\mathrm{M}-\mathrm{CH}+2 \mathrm{H}]^{+\cdot}$} & 4.1 \\
\hline & 1853.353 & 1853.348 & {$\left[\mathrm{M}-\mathrm{C}^{\cdot}+2 \mathrm{H}\right]^{+}$} & 2.7 \\
\hline & 1945.371 & & & \\
\hline & 1962.376 & 1962.376 & {$[\mathrm{M}+\mathrm{H}]^{+}$} & calibrant \\
\hline
\end{tabular}

from the radical $z$ ions, a result attributed to the lower stability of radical ions [28]. For ECD of $\mathrm{dC}_{4}$, one even-electron $(a-\mathrm{CH})$ or $(z-\mathrm{CH})$ ion is observed within experimental error. Even-electron $(a-$ base $)$ ions are seen as the ions complementary to $w$ ions in CID of protonated oligodeoxynucleotides [50-53]. In ECD, the even-electron $(a-\mathrm{CH}) /(z-\mathrm{CH})$ ion could be formed by $\mathrm{H} \cdot$ ejection combined with $\mathrm{CH}$ loss. No $(a-\mathrm{CH}) /$
$(z-\mathrm{CH})$ ions could be assigned to within experimental error following ECD of $\mathrm{dC}_{5}-\mathrm{dC}_{7}$.

Finally, ECD of $\mathrm{dC}_{5}-\mathrm{dC}_{7}$ consistently yields fragment ions that can be assigned as $w / d$ or $(w / d-\mathrm{CH})$ ions plus water. It is not likely that these ions are due to ion-molecule reactions with background water because of the low $\left(1 \times 10^{-9}\right.$ torr $)$ pressure in the FT-ICR mass analyzer. For $\mathrm{dC}_{6}$ and $\mathrm{dC}_{7}$, the $\left(w / d+\mathrm{H}_{2} \mathrm{O}\right)$ ions are 

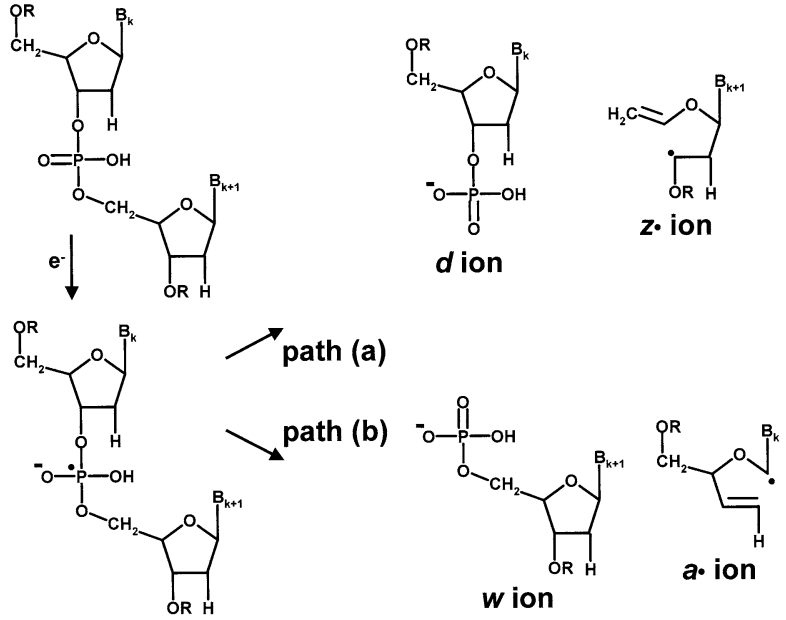

Scheme 1. Proposed mechanism for electron capture dissociation of oligonucleotides to form even-electron $d$ or $w$ ions, accompanied by radical $z \cdot$ or $a \cdot$ ions. Electron capture at the $\mathrm{P}=\mathrm{O}$ bond results in a negatively charged phosphate group. Consequently, $d$ and $w$ ions must carry at least two protons (or alkali metal adducts) to be observed, whereas one positively charged adduct is sufficient to observe $a \cdot$ and $z \cdot$ ions.

observed only for the largest possible $w / d$ ions (i.e., $w_{5} / d_{5}$ in $\mathrm{dC}_{6}$ and $w_{6} / d_{6}$ in $\mathrm{dC}_{7}$, corresponding to cleavage of the sugar-phosphate backbone closest to one of the ends). Robinson et al. have performed molecular modeling suggesting that the charged 5'- or 3'-phosphate group can bond to the free hydroxyl hydrogen of the sugar in gas-phase deprotonated mononucleotides [74]. In our experiments with protonated oligonucleotides, the phosphate groups are neutral before electron capture but a hydrogen bond between a terminal 5'- or 3'-sugar hydroxyl hydrogen and a neutral backbone phosphate oxygen could still facilitate
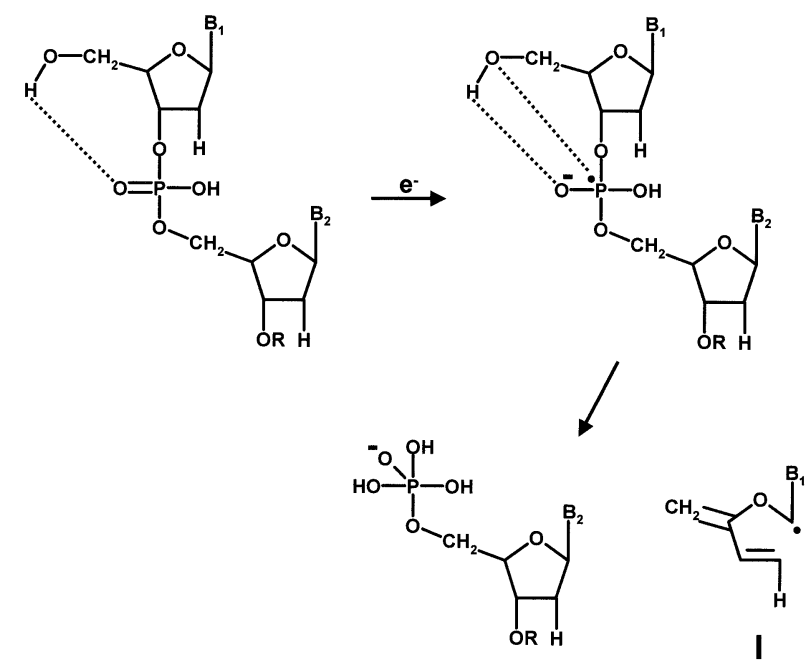

$\left(w+\mathrm{H}_{2} \mathrm{O}\right)$ ion?

Scheme 2. Intramolecular hydrogen bonding between the 5'hydroxyl hydrogen and a backbone phosphate oxygen. This hydrogen bonding is proposed to be involved in the formation of $\left(w+\mathrm{H}_{2} \mathrm{O}\right)$ ions, possibly through a pentavalent phosphorane structure and the radical $\mathbf{I}$.

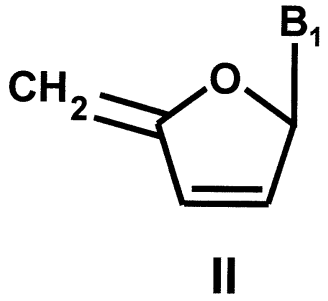

Scheme 3. A nucleoside-like even-electron fragment ion with a structure complementary to $\left(w_{n} / d_{n}+\mathrm{H}_{2} \mathrm{O}\right)$ ions. This type of fragment ion is commonly observed in CID of protonated oligonucleotides, indicating that it is relatively stable.

their interaction (see Scheme 2 for the 5'-case). Formation of fragment ions corresponding to $\left(w / d+\mathrm{H}_{2} \mathrm{O}\right)$ could possibly proceed through a pentavalent phosphorane structure (see Scheme 2), which is known to be involved in RNA hydrolysis [75-77]. Nucleoside-like fragment ions with a structure complementary to $\left(w_{\mathrm{n}} / d_{\mathrm{n}}+\mathrm{H}_{2} \mathrm{O}\right)$ (molecule II in Scheme 3) are commonly observed in CID of protonated oligonucleotides, indicating that such ions are relatively stable $[50,51]$. The radical variant that might be involved in the ECD reaction is shown as molecule $\mathbf{I}$ in Scheme 2. The abundance of $\left(w_{\mathrm{n}}+\mathrm{H}_{2} \mathrm{O}\right) /\left(d_{\mathrm{n}}+\mathrm{H}_{2} \mathrm{O}\right)$ relative to $w_{\mathrm{n}} / d_{\mathrm{n}}$ increases with the length of the polydeoxycytidine chain: for $\mathrm{dC}_{5},\left(w_{4}+\mathrm{H}_{2} \mathrm{O}\right) /\left(d_{4}+\mathrm{H}_{2} \mathrm{O}\right)$ is a minor fragment, whereas for $\mathrm{dC}_{7},\left(w_{6}+\mathrm{H}_{2} \mathrm{O}\right) /\left(d_{6}+\mathrm{H}_{2} \mathrm{O}\right)$ is more abundant than $w_{6} / d_{6}$ (Figure 1 ). That length dependence could result from the larger degree of flexibility of the longer chains, due to lower Coulomb repulsion (provided that the two protons are located at opposite ends of the molecule), thereby facilitating the formation of intramolecular hydrogen bonds.

As discussed above, only two consecutive "se-

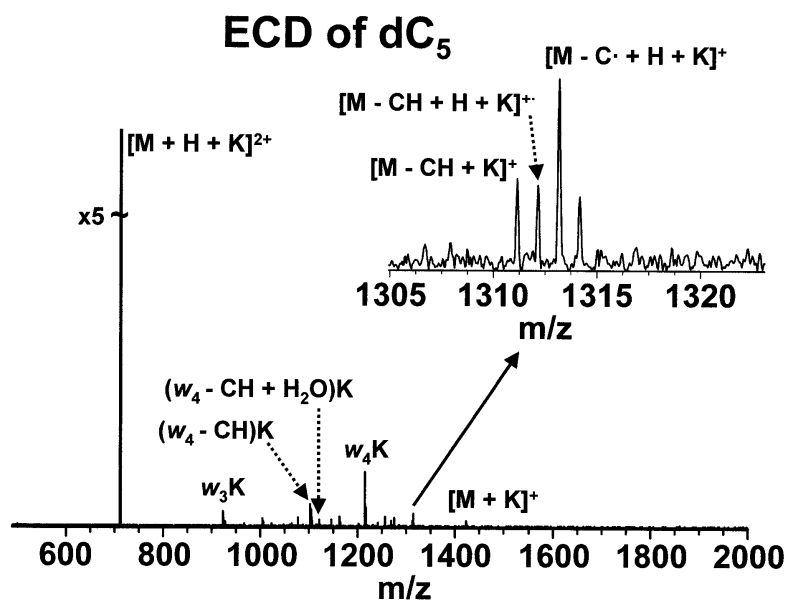

Figure 2. FT-ICR mass spectrum following ECD of protonated/ potassiated $\mathrm{dC}_{5}$ (50 scans, $30 \mathrm{~s}$ irradiation). The fragmentation pattern is very similar to the one observed in ECD of doubly protonated $\mathrm{dC}_{5}$ (see Figure 1), except for replacement of one proton by a potassium ion. The inset shows the isotopic distribution corresponding to cytosine base loss from the charge-reduced parent ion. Loss of either a neutral base $(\mathrm{CH})$ or a radical base $(\mathrm{C} \cdot)$ is seen. 
Table 2. Major fragment ions observed in ECD spectra of protonated/sodiated and protonated/potassiated $\mathrm{dC}_{4}, \mathrm{dC}_{5}$, and $\mathrm{dC}_{6}$. Ions labeled $w$ can also be $d$ ions, and ions labeled $a$ can also be $z$ ions. All spectra were internally calibrated

\begin{tabular}{|c|c|c|c|c|}
\hline Sample & Observed $\mathrm{m} / \mathrm{z}$ & Calculated $\mathrm{m} / \mathrm{z}$ & Assignment & Error (ppm) \\
\hline \multirow[t]{19}{*}{$\mathrm{dC}_{4}$} & 559.1131 & 559.1131 & {$[\mathrm{M}+\mathrm{H}+\mathrm{Na}]^{2+}$} & calibrant \\
\hline & 619.0953 & 619.0926 & $w_{2} \mathrm{Na}$ & 4.5 \\
\hline & 699.0598 & & & \\
\hline & 797.0898 & 797.0957 & $\left(w_{3}-\mathrm{CH}\right) \mathrm{Na}$ & -7.3 \\
\hline & 908.1389 & 908.1389 & $w_{3} \mathrm{Na}$ & calibrant \\
\hline & 567.1001 & 567.1001 & {$[\mathrm{M}+\mathrm{H}+\mathrm{K}]^{2+}$} & calibrant \\
\hline & 635.0642 & 635.0665 & $w_{2} \mathrm{~K}$ & 3.6 \\
\hline & 715.0298 & & & \\
\hline & 747.0942 & & & \\
\hline & 813.0671 & 813.0696 & $\left(w_{3}-\mathrm{CH}\right) \mathrm{K}$ & -3.1 \\
\hline & 827.1416 & 827.1437 & $a_{3} \mathrm{~K}$ & -2.5 \\
\hline & 868.0845 & & & \\
\hline & 924.1088 & 924.1128 & $w_{3} \mathrm{~K}$ & -4.3 \\
\hline & 950.1271 & & & \\
\hline & 966.1186 & & & \\
\hline & 979.1296 & 979.1313 & {$\left[\mathrm{M}-\mathrm{CH}-\mathrm{CH}_{3} \mathrm{CO}+\mathrm{K}\right]^{+}$} & -1.7 \\
\hline & 996.1345 & & & \\
\hline & 1022.148 & 1022.150 & {$[\mathrm{M}-\mathrm{CH}+\mathrm{K}]^{+}$} & -1.6 \\
\hline & 1133.193 & 1133.193 & {$[\mathrm{M}+\mathrm{K}]^{+}$} & calibrant \\
\hline \multirow[t]{21}{*}{$\mathrm{dC}_{5}$} & 703.6363 & 703.6363 & {$[\mathrm{M}+\mathrm{H}+\mathrm{Na}]^{2+}$} & calibrant \\
\hline & 908.1372 & 908.1389 & $w_{3} \mathrm{Na}$ & -1.8 \\
\hline & 988.1062 & & & \\
\hline & 1086.147 & 1086.142 & $\left(w_{4}-\mathrm{CH}\right) \mathrm{Na}$ & 4.3 \\
\hline & 1197.185 & 1197.185 & $w_{4} \mathrm{Na}^{+}$ & calibrant \\
\hline & 1406.270 & 1406.265 & {$[\mathrm{M}+\mathrm{Na}]^{+}$} & 3.3 \\
\hline & 711.6233 & 711.6233 & {$[\mathrm{M}+\mathrm{H}+\mathrm{K}]^{2+}$} & calibrant \\
\hline & 924.1104 & 924.1128 & $w_{3} \mathrm{~K}$ & -2.5 \\
\hline & 1004.080 & & & \\
\hline & 1076.135 & & & \\
\hline & 1102.118 & 1102.116 & $\left(w_{4}-\mathrm{CH}\right) \mathrm{K}$ & 1.9 \\
\hline & 1120.129 & 1120.127 & $\left(w_{4}+\mathrm{H}_{2} \mathrm{O}-\mathrm{CH}\right) \mathrm{K}$ & 2.1 \\
\hline & 1144.125 & & & \\
\hline & 1162.135 & & & \\
\hline & 1213.159 & 1213.159 & $w_{4} \mathrm{~K}$ & calibrant \\
\hline & 1255.164 & & & \\
\hline & 1268.180 & & & \\
\hline & 1273.180 & & & \\
\hline & 1311.192 & 1311.196 & {$[\mathrm{M}-\mathrm{CH}+\mathrm{K}]^{+}$} & -3.1 \\
\hline & 1313.211 & 1313.212 & {$[\mathrm{M}-\mathrm{C} \cdot+\mathrm{H}+\mathrm{K}]^{+}$} & -0.6 \\
\hline & 1422.239 & 1422.239 & {$[\mathrm{M}+\mathrm{K}]^{+}$} & 0.4 \\
\hline \multirow[t]{26}{*}{$\mathrm{dC}_{6}$} & 848.160 & 848.160 & {$[\mathrm{M}+\mathrm{H}+\mathrm{Na}]^{2+}$} & calibrant \\
\hline & 1197.188 & 1197.185 & $w_{4} \mathrm{Na}$ & 2.6 \\
\hline & 1277.143 & & & \\
\hline & 1375.182 & 1375.188 & $\left(w_{5}-\mathrm{CH}\right) \mathrm{Na}$ & -4.8 \\
\hline & 1389.260 & 1389.263 & $a_{5} \mathrm{Na}$ & -1.5 \\
\hline & 1393.198 & 1393.199 & $\left(w_{5}+\mathrm{H}_{2} \mathrm{O}-\mathrm{CH}\right) \mathrm{Na}$ & -0.7 \\
\hline & 1486.227 & 1486.232 & $w_{5} \mathrm{Na}$ & -3.0 \\
\hline & 1504.242 & 1504.242 & $\left(w_{5}+\mathrm{H}_{2} \mathrm{O}\right) \mathrm{Na}$ & -0.2 \\
\hline & 1514.256 & & & \\
\hline & 1528.241 & & & \\
\hline & 1546.250 & & & \\
\hline & 1585.262 & 1585.276 & {$[\mathrm{M}-\mathrm{CH}+\mathrm{H}+\mathrm{Na}]^{+\cdot}$} & -9.3 \\
\hline & 1586.272 & 1586.284 & {$[\mathrm{M}-\mathrm{C} \cdot+\mathrm{H}+\mathrm{Na}]^{+}$} & -7.5 \\
\hline & 1695.312 & 1695.312 & {$[\mathrm{M}+\mathrm{Na}]^{+}$} & calibrant \\
\hline & 856.1465 & 856.1465 & {$[\mathrm{M}+\mathrm{H}+\mathrm{K}]^{2+}$} & calibrant \\
\hline & 1213.159 & 1213.159 & $w_{4} \mathrm{~K}$ & -0.2 \\
\hline & 1293.117 & & & \\
\hline & 1391.159 & 1391.162 & $\left(w_{5}-\mathrm{CH}\right) \mathrm{K}$ & -2.5 \\
\hline & 1409.170 & 1409.173 & $\left(w_{5}+\mathrm{H}_{2} \mathrm{O}-\mathrm{CH}\right) \mathrm{K}$ & -2.4 \\
\hline & 1502.201 & 1502.206 & $w_{5} \mathrm{~K}$ & -3.0 \\
\hline & 1520.210 & 1520.216 & $\left(w_{5}+\mathrm{H}_{2} \mathrm{O}\right) \mathrm{K}$ & -4.2 \\
\hline & 1530.250 & & & \\
\hline & 1562.225 & & & \\
\hline & 1601.260 & 1601.250 & {$[\mathrm{M}-\mathrm{CH}+\mathrm{H}+\mathrm{K}]^{+\cdot}$} & 6.3 \\
\hline & 1602.252 & 1602.258 & {$[\mathrm{M}-\mathrm{C} \cdot+\mathrm{H}+\mathrm{K}]^{+}$} & -3.6 \\
\hline & 1711.286 & 1711.286 & {$[\mathrm{M}+\mathrm{K}]^{+}$} & calibrant \\
\hline
\end{tabular}


quence" ions, corresponding to the two largest $w / d$ ions, are observed for all four investigated doubly protonated polydeoxycytidine molecules. The low sequence coverage can be ascribed to the large spatial separation between the two protons at opposite ends of the molecules. According to the ECD mechanism proposed in Scheme 1, the phosphate group in a $w$ or $d$ ion is negatively charged and the product ions can therefore be observed only if they carry both protons. As the fragment ion size decreases, the likelihood of initial double protonation also decreases due to increased Coulomb repulsion. Alternatively, one terminal proton could be transferred to the particular fragment ion to form a neutral phosphate-a process that is also more likely to occur for larger fragments.

\section{ECD of Protonated/Cationized Polydeoxycytidine}

The mass spectra following ECD of protonated/sodiated and protonated/potassiated polydC are very similar to the spectra for the doubly protonated species, except that the fragment ions are observed with alkali metal adducts instead of proton adducts. An example is $\mathrm{ECD}$ of $[\mathrm{M}+\mathrm{H}+\mathrm{K}]^{2+}$ of $\mathrm{dC}_{5}$ (see Figure 2). All ions with a " $\mathrm{K}$ " label are charged by potassium ion attachment. The inset shows the isotopic distribution corresponding to base loss from the reduced species. As indicated, both loss of a neutral base $(\mathrm{CH})$ and loss of a radical base $(C \cdot)$ are observed. In addition, the loss of a neutral base from the even-electron $[\mathrm{M}+\mathrm{K}]^{+}$ion is seen.

The major fragment ions observed following ECD of protonated/cationized $\mathrm{dC}_{4}-\mathrm{dC}_{6}$ are listed in Table 2 . The parent ion signal-to-noise ratio was not sufficient to generate observable ECD products from sodiated or potassiated $\mathrm{dC}_{7}$. As for the doubly protonated species, two consecutive $w$ or $d$ "sequence" ions are observed in all spectra. Radical $a \cdot z \cdot$ ions with cation adducts are seen in the spectra of $\left[\mathrm{dC}_{4}+\mathrm{H}+\mathrm{K}\right]^{2+}$, and $\left[\mathrm{dC}_{6}+\right.$ $\mathrm{H}+\mathrm{Na}]^{2+}$. Also, $w / d$ ions with addition of water are seen in the spectra of $\left[\mathrm{dC}_{5}+\mathrm{H}+\mathrm{K}\right]^{2+},\left[\mathrm{dC}_{6}+\mathrm{H}+\right.$ $\mathrm{Na}]^{2+}$, and $\left[\mathrm{dC}_{6}+\mathrm{H}+\mathrm{K}\right]^{2+}$. The similar fragmentation patterns observed for protonated/cationized polydC and doubly protonated polydC support the mechanism proposed in Scheme 1, in which fragmentation proceeds through direct electron capture and radical formation at the phosphate (which is not protonated). An alternative mechanism, which has been proposed for peptide and protein fragmentation, involves electronproton recombination followed by ejection of a "hot" hydrogen atom that causes cleavage at sites of high hydrogen atom affinity $[15,26]$. Unfortunately, ECD of doubly cationized polydC was precluded by low ion abundance. Moreover, oligonucleotides that were not sufficiently desalted exhibited a complete loss of signal, precluding the addition of $\mathrm{NaCl}$ or similar salts to observe doubly cationized polydC. ECD of protonated/ cationized polydC yields a larger number of product ions than ECD of doubly protonated species, indicating

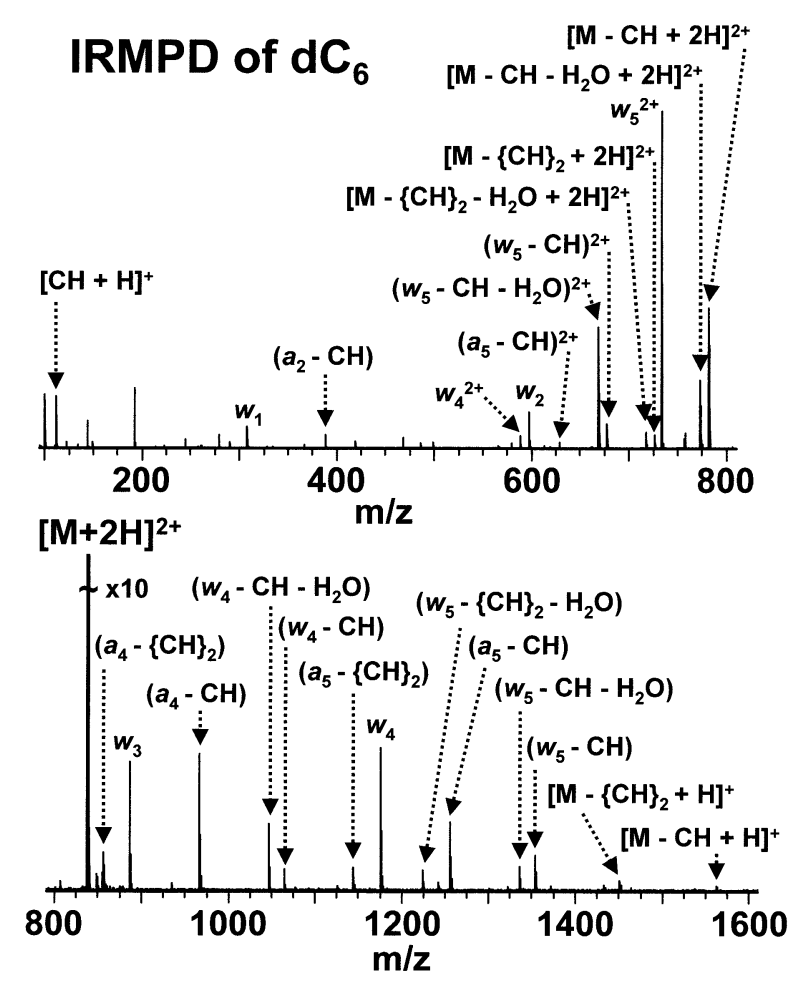

Figure 3. FT-ICR mass spectrum following IRMPD of doubly protonated $\mathrm{dC}_{6}$ ( 50 scans, $100 \mathrm{~ms}$ irradiation at $2 \mathrm{~W}$ laser power). A major fragmentation pathway is the loss of one or two neutral cytosine bases $(\mathrm{CH})$, with and without an additional loss of water, from the parent ion. Extensive backbone fragmentation, with and without base and/or water loss, resulting in all possible $w$ "sequence" ions, is also observed.

additional fragmentation pathways. For example, one fragment ion from ECD of $[\mathrm{M}+\mathrm{H}+\mathrm{K}]^{2+}$ of $\mathrm{dC}_{4}$ could be assigned as the loss of a neutral cytosine base and an additional $\mathrm{CH}_{3} \mathrm{CO}$ group. This loss could be due to cleavage across the sugar, as observed by McLuckey et al. in CID of radical deoxynucleotide anions [23].

\section{IRMPD of Doubly Protonated Polydeoxycytidine}

The IRMPD fragmentation pathways observed for doubly protonated polydC are very similar to the ones established for CID of singly- [48, 49] or multiply[50-53] protonated oligonucleotides. As an example, the mass spectrum following IRMPD of doubly protonated $\mathrm{dC}_{6}$ is shown in Figure 3.

The major fragment ions observed from IRMPD of doubly protonated $\mathrm{dC}_{4}-\mathrm{dC}_{7}$ are collected in Table 3 . In all cases, a major pathway is the loss of one or two cytosine bases from the parent ion. The complementary $[\mathrm{CH}+\mathrm{H}]^{+}$ion is also seen. Loss of water in combination with base loss from the parent ion is observed in many cases. Such fragmentation was also seen in CID of oligonucleotide anions [45]. In those experiments, it was found that water loss stemmed from the 3' end. We also observe backbone "sequence" ions of the $w /(a-\mathrm{CH})$ or $d /(z-\mathrm{CH})$ types. In contrast to ECD, fragments corresponding to cleavage along the entire sugar-phos- 
Table 3. Major fragment ions observed following IRMPD of doubly protonated $\mathrm{dC}_{4}, \mathrm{dC}_{5}, \mathrm{dC}_{6}$, and $\mathrm{dC}_{7}$. Ions labeled $w$ can also be $d$ ions, and ions labeled $a$ can also be $z$ ions. All spectra were internally calibrated

\begin{tabular}{|c|c|c|c|c|c|}
\hline Sample & Observed $\mathrm{m} / \mathrm{z}$ & Charge & Calculated $\mathrm{m} / \mathrm{z}$ & Assignment & Error (ppm) \\
\hline \multirow[t]{18}{*}{$\mathrm{dC}_{4}$} & 100.1123 & 1 & & & \\
\hline & 112.0508 & 1 & 112.0505 & {$[\mathrm{CH}+\mathrm{H}]^{+}$} & 2.6 \\
\hline & 144.0423 & 1 & & & \\
\hline & 182.7184 & $6^{*}$ & & $3^{\text {rd }}$ harmonic & \\
\hline & 443.5826 & 2 & 443.5821 & $\mathrm{w}_{3}^{2+}$ & 1.2 \\
\hline & 483.5957 & 2 & 483.5952 & {$\left[\mathrm{M}-\mathrm{CH}-\mathrm{H}_{2} \mathrm{O}+2 \mathrm{H}\right]^{2+}$} & 0.9 \\
\hline & 492.6006 & 2 & 492.6005 & {$[\mathrm{M}-\mathrm{CH}+2 \mathrm{H}]^{2+}$} & 0.2 \\
\hline & 499.1051 & 2 & & & \\
\hline & 548.1221 & 2 & 548.1221 & {$[\mathrm{M}+2 \mathrm{H}]^{2+}$} & calibrant \\
\hline & 597.1099 & 1 & 597.1106 & $w_{2}$ & -1.2 \\
\hline & 677.1368 & ? & 677.1368 & $\left(a_{3}-\mathrm{CH}\right)$ & 0.08 \\
\hline & 757.1025 & 1 & 757.1031 & $\left(w_{3}-\mathrm{CH}-\mathrm{H}_{2} \mathrm{O}\right)$ & -0.8 \\
\hline & 775.1149 & 1 & 775.1137 & $\left(w_{3}-\mathrm{CH}\right)$ & 1.6 \\
\hline & 855.1404 & 1 & & & \\
\hline & 873.1502 & 1 & & & \\
\hline & 886.1569 & 1 & 886.1569 & $w_{3}$ & calibrant \\
\hline & 966.1815 & 1 & 966.1832 & {$\left[\mathrm{M}-\mathrm{CH}-\mathrm{H}_{2} \mathrm{O}+\mathrm{H}\right]^{+}$} & -1.7 \\
\hline & 984.1919 & 1 & 984.1938 & {$[\mathrm{M}-\mathrm{CH}+\mathrm{H}]^{+}$} & -1.9 \\
\hline \multirow[t]{23}{*}{$\mathrm{dC}_{5}$} & 100.1127 & 1 & & & \\
\hline & 112.0512 & 1 & 112.0505 & {$[\mathrm{CH}+\mathrm{H}]^{+}$} & 6.5 \\
\hline & 144.0428 & 1 & & & \\
\hline & 230.8982 & $6^{*}$ & & $3^{\text {rd }}$ harmonic & \\
\hline & 308.0658 & 1 & 308.0642 & $w_{1}$ & 5.3 \\
\hline & 346.3240 & $4^{*}$ & & $2^{\text {nd }}$ harmonic & \\
\hline & 388.0923 & 1 & 388.0905 & $\left(\mathrm{a}_{2}-\mathrm{CH}\right)$ & 4.7 \\
\hline & 419.1092 & 1 & & & \\
\hline & 588.1074 & 2 & 588.1053 & $w_{4}^{2+}$ & 3.6 \\
\hline & 597.1123 & 1 & 597.1106 & $w_{2}$ & 2.9 \\
\hline & 628.1195 & 2 & 628.1184 & {$\left[\mathrm{M}-\mathrm{CH}-\mathrm{H}_{2} \mathrm{O}+2 \mathrm{H}\right]^{2+}$} & 1.7 \\
\hline & 637.1253 & 2 & 637.1237 & {$[\mathrm{M}-\mathrm{CH}+2 \mathrm{H}]^{2+}$} & 2.5 \\
\hline & 677.1391 & 1 & 677.1368 & $\left(a_{3}-\mathrm{CH}\right)$ & 3.6 \\
\hline & 692.6453 & 2 & 692.6453 & {$[\mathrm{M}+2 \mathrm{H}]^{2+}$} & calibrant \\
\hline & 757.1049 & 1 & 757.1031 & $\left(w_{3}-\mathrm{CH}-\mathrm{H}_{2} \mathrm{O}\right)$ & 2.4 \\
\hline & 886.1588 & 1 & 886.1569 & $w_{3}$ & 2.1 \\
\hline & 966.1810 & 1 & 966.1832 & $\left(a_{4}-\mathrm{CH}\right)$ & -2.3 \\
\hline & 1046.150 & 1 & 1046.150 & $\left(w_{4}-\mathrm{CH}-\mathrm{H}_{2} \mathrm{O}\right)$ & 0.7 \\
\hline & 1064.160 & 1 & 1064.160 & $\left(w_{4}-\mathrm{CH}\right)$ & -0.1 \\
\hline & 1144.186 & 1 & 1144.186 & {$\left[\mathrm{M}-\{\mathrm{CH}\}_{2}-\mathrm{H}_{2} \mathrm{O}+\mathrm{H}\right]^{+}$} & -0.2 \\
\hline & 1162.195 & 1 & 1162.197 & {$\left[\mathrm{M}-\{\mathrm{CH}\}_{2}+\mathrm{H}\right]^{+}$} & -2.0 \\
\hline & 1175.203 & 1 & 1175.203 & $w_{4}$ & calibrant \\
\hline & 1273.238 & 1 & 1273.240 & {$[\mathrm{M}-\mathrm{CH}+\mathrm{H}]^{+}$} & -1.7 \\
\hline \multirow[t]{19}{*}{$\mathrm{dC}_{6}$} & 100.1130 & 1 & & & \\
\hline & 112.0516 & 1 & 112.0505 & {$[\mathrm{CH}+\mathrm{H}]^{+}$} & 9.7 \\
\hline & 144.0433 & 1 & & & \\
\hline & 192.0784 & 1 & & & \\
\hline & 244.2320 & $6^{*}$ & & $3^{\text {rd }}$ harmonic & \\
\hline & 279.0841 & $6^{*}$ & & $3^{\text {rd }}$ harmonic & \\
\hline & 308.0667 & 1 & 308.0642 & $w_{1}$ & 8.3 \\
\hline & 366.3163 & $4^{*}$ & & $2^{\text {nd }}$ harmonic & \\
\hline & 388.0930 & 1 & 388.0905 & $\left(a_{2}-\mathrm{CH}\right)$ & 6.6 \\
\hline & 418.5870 & $4^{*}$ & & $2^{\text {nd }}$ harmonic & \\
\hline & 468.0596 & 1 & & & \\
\hline & 499.1374 & 1 & & & \\
\hline & 579.1021 & 1 & & & \\
\hline & 588.1021 & 2 & 588.1053 & $w_{4}^{2+}$ & -5.5 \\
\hline & 597.1130 & 1 & 597.1106 & $w_{2}$ & 4.1 \\
\hline & 628.0923 & 2 & & & \\
\hline & 668.1055 & 2 & 668.1016 & $\left(w_{5}-\mathrm{CH}-\mathrm{H}_{2} \mathrm{O}\right)^{2+}$ & 5.9 \\
\hline & 677.1336 & 2 & 677.1069 & & \\
\hline & 717.1233 & 2 & 717.1200 & {$\left[\mathrm{M}-\{\mathrm{CH}\}_{2}-\mathrm{H}_{2} \mathrm{O}+2 \mathrm{H}\right]^{2+}$} & 4.6 \\
\hline
\end{tabular}


Table 3. (continued)

\begin{tabular}{|c|c|c|c|c|c|}
\hline Sample & Observed $\mathrm{m} / \mathrm{z}$ & Charge & Calculated $\mathrm{m} / \mathrm{z}$ & Assignment & Error $(\mathrm{ppm})$ \\
\hline & 726.1268 & 2 & 726.1253 & {$\left[\mathrm{M}-\{\mathrm{CH}\}_{2}+2 \mathrm{H}\right]^{2+}$} & 2.0 \\
\hline & 732.5433 & 2 & 732.6285 & & \\
\hline & 757.1076 & 1 & 757.1031 & $\left(w_{3}-\mathrm{CH}-\mathrm{H}_{2} \mathrm{O}\right)$ & 5.9 \\
\hline & 772.6439 & 2 & 772.6416 & {$\left[\mathrm{M}-\mathrm{CH}-\mathrm{H}_{2} \mathrm{O}+2 \mathrm{H}\right]^{2+}$} & 2.9 \\
\hline & 781.6494 & 2 & 781.6469 & {$[\mathrm{M}-\mathrm{CH}+2 \mathrm{H}]^{2+}$} & 1.9 \\
\hline & 837.1685 & 2 & 837.1685 & {$[\mathrm{M}+2 \mathrm{H}]^{2+}$} & calibrant \\
\hline & 848.1615 & 2 & 848.1595 & {$[\mathrm{M}+\mathrm{H}+\mathrm{Na}]^{2+}$} & 2.3 \\
\hline & 856.1435 & 2 & 856.1465 & {$[\mathrm{M}+\mathrm{H}+\mathrm{K}]^{2+}$} & -3.5 \\
\hline & 886.1589 & 1 & 886.1569 & $w_{3}$ & 2.3 \\
\hline & 966.1814 & 1 & 966.1832 & $\left(a_{4}-\mathrm{CH}\right)$ & -1.9 \\
\hline & 1046.150 & 1 & 1046.150 & $\left(w_{4}-\mathrm{CH}-\mathrm{H}_{2} \mathrm{O}\right)$ & 0.8 \\
\hline & 1064.162 & 1 & 1064.160 & $\left(w_{4}-\mathrm{CH}\right)$ & 2.1 \\
\hline & 1144.209 & 1 & 1144.186 & & \\
\hline & 1175.203 & 1 & 1175.203 & $w_{4}$ & calibrant \\
\hline & 1224.150 & 1 & 1224.153 & $\left(w_{5}-\{\mathrm{CH}\}_{2}-\mathrm{H}_{2} \mathrm{O}\right)$ & -2.1 \\
\hline & 1255.244 & 1 & 1255.230 & & \\
\hline & 1335.191 & 1 & 1335.196 & $\left(w_{5}-\mathrm{CH}-\mathrm{H}_{2} \mathrm{O}\right)$ & -3.8 \\
\hline & 1353.202 & 1 & 1353.207 & $\left(w_{5}-\mathrm{CH}\right)$ & -3.4 \\
\hline \multirow[t]{14}{*}{$\mathrm{dC}_{7}$} & 327.2639 & $6^{*}$ & & $3^{\text {rd }}$ harmonic & \\
\hline & 490.8462 & $4^{*}$ & & $2^{\text {nd }}$ harmonic & \\
\hline & 597.1106 & $?$ & 597.1106 & $w_{2}$ & calibrant \\
\hline & 677.1393 & 1 & 677.1368 & $\left(a_{3}-\mathrm{CH}\right)$ & 3.7 \\
\hline & 821.6326 & 2 & 821.6301 & $\left(w_{6}-\mathrm{CH}\right)^{2+}$ & 3.1 \\
\hline & 861.6454 & 2 & 861.6432 & {$\left[\mathrm{M}-\{\mathrm{CH}\}_{2}-\mathrm{H}_{2} \mathrm{O}+2 \mathrm{H}\right]^{2+}$} & 2.6 \\
\hline & 870.6524 & 2 & 870.6485 & {$\left[\mathrm{M}-\{\mathrm{CH}\}_{2}+2 \mathrm{H}\right]^{2+}$} & -4.5 \\
\hline & 877.1543 & 2 & 877.1517 & $w_{6}^{2+}$ & 3.0 \\
\hline & 886.1606 & 1 & 886.1569 & $w_{3}$ & 4.2 \\
\hline & 917.1684 & 2 & 917.1648 & {$\left[\mathrm{M}-\mathrm{CH}-\mathrm{H}_{2} \mathrm{O}+2 \mathrm{H}\right]^{2+}$} & 4.0 \\
\hline & 926.1744 & 2 & 926.1701 & {$[\mathrm{M}-\mathrm{CH}+2 \mathrm{H}]^{2+}$} & 4.7 \\
\hline & 966.1859 & 1 & 966.1832 & $\left(a_{4}-\mathrm{CH}\right)$ & 2.8 \\
\hline & 981.6917 & 2 & 981.69178 & {$[\mathrm{M}+2 \mathrm{H}]^{2+}$} & calibrant \\
\hline & 1175.210 & 1 & 1175.203 & $w_{4}$ & 6.1 \\
\hline
\end{tabular}

* = apparent charge

?= only one isotopic peak was observed

phate backbone are observed. The spectra of $\mathrm{dC}_{5}$ and $\mathrm{dC}_{6}$ contain all possible $w / d$ ions. However, the IRMPD results are more tedious to interpret because almost every "sequence" ion also appears after loss of one or two bases, and after loss of one/two bases and water, rendering the spectra more complicated. The observation of low-abundance sodiated and potassiated parent ions in the $\mathrm{dC}_{6}$ spectrum is due to poor SWIFT isolation.

\section{IRMPD of Protonated/Cationized Polydeoxycytidine}

As for ECD, the mass spectra following IRMPD of protonated/sodiated and protonated/potassiated polydeoxycytidine are very similar to the corresponding spectra of the doubly protonated ions, except that most fragment ions are observed with alkali metal adducts instead of proton adducts (data not shown).

\section{ECD of Doubly Protonated Polydeoxyguanosine}

Mass spectra following ECD of doubly protonated $\mathrm{dG}_{5}$ and $d G_{7}$ are shown in Figure 4 and the major fragment ions are assembled in Table 4 . In the spectrum of $\mathrm{dG}_{5}$, two consecutive "sequence" ions could be identified as $w_{3} / d_{3}$ and $w_{4} / d_{4}$, but with a mass 1 Da higher than expected from the mechanism in Scheme 1. Possibly, these $w_{\mathrm{n}} \mathrm{H} \cdot / d_{\mathrm{n}} \mathrm{H} \cdot$ ions are formed by intramolecular hydrogen atom transfer. The gas-phase hydrogen/deuterium (H/D) exchange rate has been shown to be considerably slower for deoxyguanosine 5'-monophosphate anions (5'-dGMP) compared to the other deoxynucleoside 5'-monophosphates [74, 78]: The slow exchange for 5'-dGMP was attributed to a gas-phase syn conformation, in which the amino group of guanine interacts with the negatively charged phosphate group [74]. Slower gas-phase H/D exchange for purines compared to pyrimidines was also found for protonated mononucleotides [79]. Semiempirical calculations had previously demonstrated internal hydrogen bonding in gas-phase protonated purine nucleotides [80]. Finally, Griffey et al. have suggested that oligonucleotides containing few dG nucleosides form fewer internal hydrogen bonds in the gas phase than dG-rich sequences [81]. Extensive gas-phase internal hydrogen bonding should facilitate hydrogen atom transfer and might explain the 


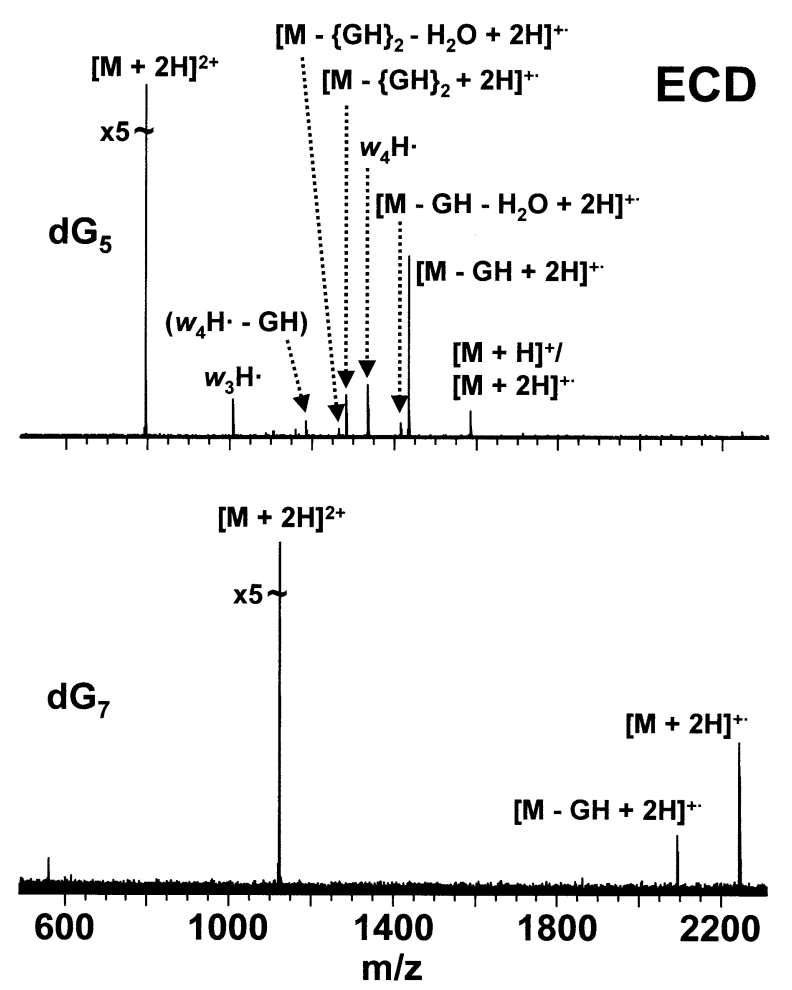

Figure 4. FT-ICR mass spectra following ECD of doubly protonated $\mathrm{dG}_{5}$ and $\mathrm{dG}_{7}$ (50 scans, $30 \mathrm{~s}$ irradiation). In both spectra, the major fragments correspond to loss of a neutral guanine base $(\mathrm{GH})$ from the reduced species. For $\mathrm{dG}_{5}$, loss of two bases and (base + water) loss is also seen. The observed $w / d$ ions (labeled $\left.w_{\mathrm{n}} \mathrm{H} \cdot\right)$ are 1 Da heavier than expected, presumably due to intramolecular hydrogen atom transfer (see text).

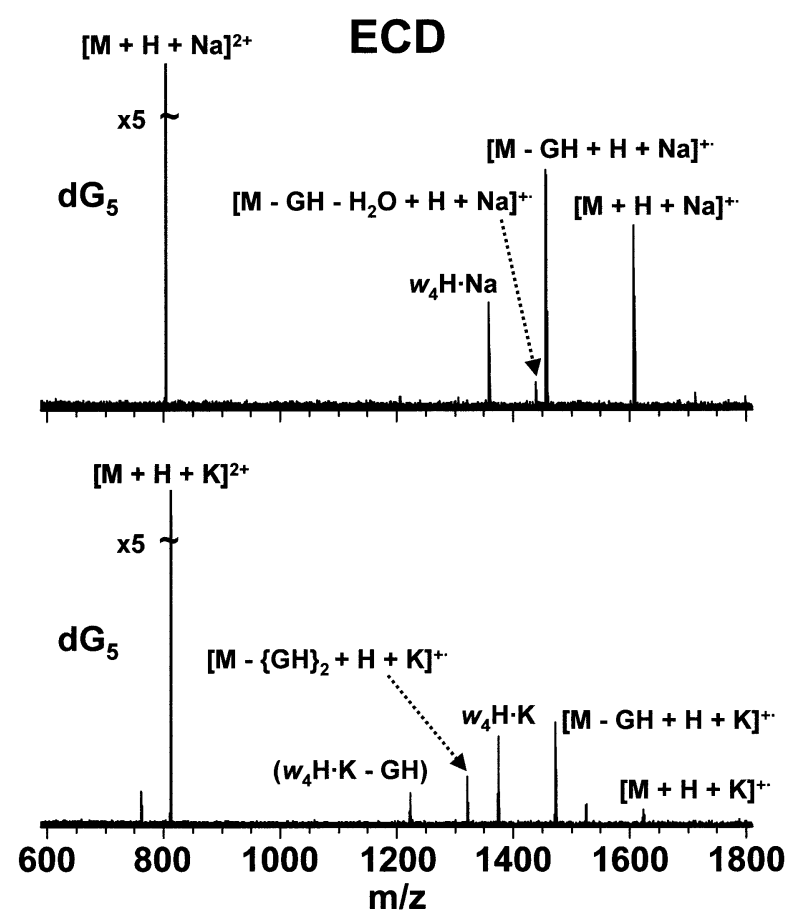

Figure 5. FT-ICR mass spectra following ECD of protonated/ sodiated and protonated/potassiated $\mathrm{dG}_{5}$ (50 scans, $30 \mathrm{~s}$ irradiation). As for ECD of the doubly protonated species (Figure 4), loss of neutral guanine $(\mathrm{GH})$ is the major fragmentation pathway. The $w_{4} \mathrm{H} \cdot / d_{\mathrm{n}} \mathrm{H}$ ions are observed with sodium or potassium adducts, as indicated by "Na" and " $\mathrm{K}$ " labels.

Table 4. Major fragment ions observed in $\mathrm{ECD}$ spectra of doubly protonated $\mathrm{dG}_{5}$ and $\mathrm{dG}_{7}$. Ions labeled $w$ can also be $d$ ions. The spectra were internally calibrated

\begin{tabular}{|c|c|c|c|c|}
\hline Sample & Observed $\mathrm{m} / \mathrm{z}$ & Calculated $\mathrm{m} / \mathrm{z}$ & Assignment & Error (ppm) \\
\hline \multirow[t]{17}{*}{$\mathrm{dG}_{5}$} & 152.0575 & 152.0567 & {$[\mathrm{GH}+\mathrm{H}]^{+}$} & 5.3 \\
\hline & 264.2424 & & $3^{\text {rd }}$ harmonic & \\
\hline & 292.9895 & & & \\
\hline & 361.9868 & & & \\
\hline & 396.3317 & & $2^{\text {nd }}$ harmonic & \\
\hline & 792.6607 & 792.6607 & {$[\mathrm{M}+2 \mathrm{H}]^{2+}$} & calibrant \\
\hline & 1007.184 & 1007.183 & $w_{3} \mathrm{H} \cdot$ & 0.6 \\
\hline & 1105.219 & & & \\
\hline & 1158.229 & & & \\
\hline & 1185.183 & 1185.187 & $\left(w_{4} \mathrm{H} \cdot-\mathrm{GH}\right)$ & -3.0 \\
\hline & 1265.221 & 1265.213 & {$\left[\mathrm{M}-\{\mathrm{GH}\}_{2}-\mathrm{H}_{2} \mathrm{O}+2 \mathrm{H}\right]^{+\cdot}$} & 6.4 \\
\hline & 1283.225 & 1283.223 & {$\left[\mathrm{M}-\{\mathrm{GH}\}_{2}+2 \mathrm{H}\right]^{+\cdot}$} & 1.7 \\
\hline & 1336.234 & 1336.236 & $w_{4} \mathrm{H} \cdot$ & -1.6 \\
\hline & 1416.260 & 1416.262 & {$\left[\mathrm{M}-\mathrm{GH}-\mathrm{H}_{2} \mathrm{O}+2 \mathrm{H}\right]^{+\cdot}$} & -1.3 \\
\hline & 1434.273 & 1434.273 & {$[\mathrm{M}-\mathrm{GH}+2 \mathrm{H}]^{+\cdot}$} & calibrant \\
\hline & 1584.311 & 1584.314 & {$[\mathrm{M}+\mathrm{H}]^{+}$} & -1.7 \\
\hline & 1585.315 & 1585.322 & {$[\mathrm{M}+2 \mathrm{H}]^{+\cdot}$} & -4.1 \\
\hline \multirow[t]{6}{*}{$\mathrm{dG}_{7}$} & 152.0571 & 152.0567 & {$[\mathrm{GH}+\mathrm{H}]^{+}$} & 3.0 \\
\hline & 373.9444 & & $3^{\text {rd }}$ harmonic & \\
\hline & 560.8592 & & $2^{\text {nd }}$ harmonic & \\
\hline & 1121.713 & 1121.713 & {$[\mathrm{M}+2 \mathrm{H}]^{2+}$} & calibrant \\
\hline & 2092.391 & 2092.378 & {$[\mathrm{M}-\mathrm{GH}+2 \mathrm{H}]^{+\cdot}$} & 6.4 \\
\hline & 2243.427 & 2243.427 & {$[\mathrm{M}+2 \mathrm{H}]^{+\cdot}$} & calibrant \\
\hline
\end{tabular}


Table 5. Major fragment ions observed in ECD spectra of protonated/sodiated and protonated/potassiated $\mathrm{dG}_{5}$. Ions labeled $w$ can also be $d$ ions. The spectra were internally calibrated

\begin{tabular}{|c|c|c|c|c|}
\hline Sample & Observed $\mathrm{m} / \mathrm{z}$ & Calculated $\mathrm{m} / \mathrm{z}$ & Assignment & Error (ppm) \\
\hline \multirow[t]{28}{*}{$\mathrm{dG}_{5}$} & 152.0580 & 152.0567 & {$[\mathrm{GH}+\mathrm{H}]^{+}$} & 8.8 \\
\hline & 803.6517 & 803.6517 & {$[\mathrm{M}+\mathrm{H}+\mathrm{Na}]^{2+}$} & calibrant \\
\hline & 1357.202 & 1357.210 & $w_{4} \mathrm{Na}$ & -5.7 \\
\hline & 1358.209 & 1358.218 & $w_{4} \mathrm{H} \cdot \mathrm{Na}$ & -6.4 \\
\hline & 1438.238 & 1438.244 & {$\left[\mathrm{M}-\mathrm{GH}-\mathrm{H}_{2} \mathrm{O}+\mathrm{H}+\mathrm{Na}\right]^{+\cdot}$} & -4.1 \\
\hline & 1455.230 & 1455.247 & {$[\mathrm{M}-\mathrm{GH}+\mathrm{Na}]^{+}$} & -12 \\
\hline & 1456.249 & & {$[\mathrm{M}-\mathrm{GH}+\mathrm{H}+\mathrm{Na}]^{+\cdot}$} & -4.1 \\
\hline & 1456.254 & & & \\
\hline & 1606.296 & 1606.296 & {$[\mathrm{M}+\mathrm{Na}]^{+}$} & calibrant \\
\hline & 1607.302 & 1607.304 & {$[\mathrm{M}+\mathrm{H}+\mathrm{Na}]^{+\cdot}$} & -1.2 \\
\hline & 152.0573 & 152.0567 & {$[\mathrm{GH}+\mathrm{H}]^{+}$} & 3.8 \\
\hline & 261.9899 & & & \\
\hline & 270.5685 & & $3^{\text {rd }}$ harmonic & \\
\hline & 292.9892 & & & \\
\hline & 361.9873 & & & \\
\hline & 405.8190 & & $2^{\text {nd }}$ harmonic & \\
\hline & 762.6219 & & & \\
\hline & 811.6386 & 811.6386 & {$[\mathrm{M}+\mathrm{H}+\mathrm{K}]^{2+}$} & calibrant \\
\hline & 1222.138 & 1222.134 & $\left(w_{4}-\mathrm{GH}\right) \mathrm{K}$ & 2.7 \\
\hline & 1223.145 & 1223.142 & $\left(w_{4} \mathrm{H} \cdot-\mathrm{GH}\right) \mathrm{K}$ & 1.9 \\
\hline & 1321.186 & 1321.179 & {$\left[\mathrm{M}-\{\mathrm{GH}\}_{2}+\mathrm{H}+\mathrm{K}\right]^{+\cdot}$} & 5.5 \\
\hline & 1373.191 & 1373.184 & $w_{4} \mathrm{~K}$ & 5.2 \\
\hline & 1374.196 & 1374.192 & $w_{4} \mathrm{H} \cdot \mathrm{K}$ & 3.4 \\
\hline & 1471.226 & 1471.221 & {$[\mathrm{M}-\mathrm{GH}+\mathrm{K}]^{+}$} & 4.0 \\
\hline & 1472.236 & 1472.228 & {$[\mathrm{M}-\mathrm{GH}+\mathrm{H}+\mathrm{K}]^{+\cdot}$} & 5.1 \\
\hline & 1525.253 & & & \\
\hline & 1622.270 & 1622.270 & {$[\mathrm{M}+\mathrm{K}]^{+}$} & calibrant \\
\hline & 1623.296 & 1623.278 & {$[\mathrm{M}+\mathrm{H}+\mathrm{K}]^{+\cdot}$} & 11 \\
\hline
\end{tabular}

observed ECD fragment ion structure. Guanine is also the preferred oxidation site in radiation-induced damage of DNA [35, 82], suggesting that guanine-based radicals are relatively stable. Note that all of the major ECD fragment ions in the mass spectra of $\mathrm{dG}_{5}$ and $\mathrm{dG}_{7}$ are radical ions (Figure 4). The formation of radical $w / d$ ions should be accompanied by even-electron $a / z$ ions. However, no even-electron $a / z$ ions were observed, nor any $(a-\mathrm{GH})$ or $(z-\mathrm{GH})$ ions.

In contrast to ECD of polydC, the major fragment observed in ECD of polydG corresponds to the loss of a nucleobase. Another major fragment in the spectrum of $\mathrm{dG}_{5}$ corresponds to the loss of two guanine bases. The isotopic distributions indicate mixtures of even-electron ions, $[\mathrm{M}-\mathrm{GH}+\mathrm{H}]^{+} /\left[\mathrm{M}-\{\mathrm{GH}\}_{2}+\mathrm{H}\right]^{+}$, and radical ions, $[\mathrm{M}-\mathrm{GH}+2 \mathrm{H}]^{+\cdot} /\left[\mathrm{M}-\{\mathrm{GH}\}_{2}+2 \mathrm{H}\right]^{+*}$; the radical ions are the major components. The same pattern is observed for the isotopic distribution of the reduced parent ion, in which the major peak corresponds to $[\mathrm{M}+2 \mathrm{H}]^{+\cdot}$. A peak corresponding to a protonated guanine base is seen in the low-mass region of the spectra of both $\mathrm{dG}_{5}$ and $\mathrm{dG}_{7}$ (see Table 4). Protonated cytosine was not observed from ECD of polydC, consistent with base loss as a minor fragmentation pathway for polydC (see above). In ECD of PNA's, guanine loss was the most prominent base loss [18]. In our current experiments, guanine base loss was also seen together with water loss (Figure 4).
In addition to base loss, ECD of polydG differs from polydC in that no $\left(w+\mathrm{H}_{2} \mathrm{O}\right) /\left(d+\mathrm{H}_{2} \mathrm{O}\right)$ ions are seen. The $\left(w+\mathrm{H}_{2} \mathrm{O}\right) /\left(d+\mathrm{H}_{2} \mathrm{O}\right)$ ions observed in ECD of polydC are proposed to result from gas-phase hydrogen bonding between a phosphate group and a free hydroxyl group of a terminal sugar (see Scheme 2). As discussed above, the phosphate groups in polydG are likely to instead be hydrogen bonded to the guanine bases, explaining the absence of $\left(w+\mathrm{H}_{2} \mathrm{O}\right) /\left(d+\mathrm{H}_{2} \mathrm{O}\right)$ ions.

\section{ECD of Protonated/Cationized Polydeoxyguanosine}

Mass spectra following ECD of protonated/sodiated and protonated/potassiated $\mathrm{dG}_{5}$ are shown in Figure 5, with the major fragment ions listed in Table 5. The parent ion signal-to-noise ratio was not sufficient to yield observable ECD fragments of sodiated or potassiated $\mathrm{dG}_{7}$. As for ECD of doubly protonated $\mathrm{dG}_{5}$ and $\mathrm{dG}_{7}$, the major fragment ion observed from protonated/cationized $\mathrm{dG}_{5}$ is the loss of a guanine base. Loss of two bases is seen in the ECD of protonated/potassiated $\mathrm{dG}_{5}$. A peak corresponding to a protonated guanine base is seen in the low-mass region of both spectra (see Table 5).

Only one "sequence" ion, corresponding to $w_{4} \mathrm{H} \cdot /$ $d_{4} \mathrm{H} \cdot$ with a sodium or potassium adduct, was observed from ECD of both sodiated and potassiated $\mathrm{dG}_{5}$. The 
Table 6. Major fragment ions observed following IRMPD of doubly protonated, $\mathrm{dG}_{5}$ and $\mathrm{dG}_{7}$. Ions labeled $w$ can also be $d$ ions, and ions labeled $a$ can also be $z$ ions. The spectra were internally calibrated

\begin{tabular}{|c|c|c|c|c|c|}
\hline Sample & Observed $\mathrm{m} / \mathrm{z}$ & Charge & Calculated $\mathrm{m} / \mathrm{z}$ & Assignment & Error (ppm) \\
\hline \multirow[t]{23}{*}{$\mathrm{dG}_{5}$} & 100.1125 & $?$ & & & \\
\hline & 152.0572 & 1 & 152.0567 & {$[\mathrm{GH}+\mathrm{H}]^{+}$} & 3.4 \\
\hline & 232.0837 & $?$ & & & \\
\hline & 239.0644 & $6^{*}$ & & $3^{\text {rd }}$ harmonic & \\
\hline & 264.2424 & $6^{*}$ & & $3^{\text {rd }}$ harmonic & \\
\hline & 396.3318 & $4^{*}$ & & $2^{\text {nd }}$ harmonic & \\
\hline & 428.0979 & $?$ & 428.0966 & $\left(a_{2}-\mathrm{GH}\right)$ & 3.2 \\
\hline & 583.5890 & 2 & 583.5876 & $\left(w_{4}-\mathrm{GH}-\mathrm{H}_{2} \mathrm{O}\right)^{2+}$ & 2.4 \\
\hline & 632.6072 & 2 & & & \\
\hline & 641.6112 & 2 & & & \\
\hline & 668.1186 & 2 & 668.1176 & $w_{4}^{2+}$ & 1.5 \\
\hline & 677.1260 & $?$ & 677.1229 & $w_{2}$ & 4.6 \\
\hline & 708.1309 & 2 & 708.1307 & {$\left[\mathrm{M}-\mathrm{GH}-\mathrm{H}_{2} \mathrm{O}+2 \mathrm{H}\right]^{2+}$} & 0.4 \\
\hline & 717.1366 & 2 & 717.1360 & {$[\mathrm{M}-\mathrm{GH}+2 \mathrm{H}]^{2+}$} & 0.9 \\
\hline & 743.6426 & 2 & & & \\
\hline & 792.6607 & 2 & 792.6607 & {$[\mathrm{M}+2 \mathrm{H}]^{2+}$} & calibrant \\
\hline & 1006.175 & 1 & 1006.175 & $w_{3}$ & 0.06 \\
\hline & 1166.167 & 1 & 1166.168 & $\left(w_{4}-\mathrm{GH}-\mathrm{H}_{2} \mathrm{O}\right)$ & -0.5 \\
\hline & 1184.175 & 1 & 1184.178 & $\left(w_{4}-\mathrm{GH}\right)$ & -2.6 \\
\hline & 1264.207 & 1 & 1264.205 & {$\left[\mathrm{M}-\{\mathrm{GH}\}_{2}-\mathrm{H}_{2} \mathrm{O}+\mathrm{H}\right]^{+}$} & 1.6 \\
\hline & 1282.216 & 1 & 1282.215 & {$\left[\mathrm{M}-\{\mathrm{GH}\}_{2}+\mathrm{H}\right]^{+}$} & 0.8 \\
\hline & 1335.225 & 1 & 1335.228 & $w_{4}$ & -2.1 \\
\hline & 1433.265 & 1 & 1433.265 & {$[\mathrm{M}-\mathrm{GH}+\mathrm{H}]^{+}$} & calibrant \\
\hline \multirow[t]{7}{*}{$\mathrm{dG}_{7}$} & 100.1102 & $?$ & & & \\
\hline & 152.0539 & $?$ & 152.0567 & {$[\mathrm{GH}+\mathrm{H}]^{+}$} & -18 \\
\hline & 921.6424 & 2 & 921.6454 & $\left(w_{6}-\mathrm{GH}\right)^{2+}$ & 3.3 \\
\hline & 970.6638 & 2 & 970.6638 & {$\left[\mathrm{M}-\{\mathrm{GH}\}_{2}+2 \mathrm{H}\right]^{+}$} & calibrant \\
\hline & 997.1712 & 2 & 997.1701 & $w_{6}{ }^{2+}$ & 1.1 \\
\hline & 1046.188 & 2 & 1046.189 & {$[\mathrm{M}-\mathrm{GH}+2 \mathrm{H}]^{+}$} & 0.04 \\
\hline & 1121.713 & 2 & 1121.713 & {$[\mathrm{M}+2 \mathrm{H}]^{+}$} & calibrant \\
\hline
\end{tabular}

* = apparent charge

$?=$ only one isotopic peak was observed

isotopic distributions of these ions show the presence of both the radical ion, $w_{4} \mathrm{H} \cdot / d_{4} \mathrm{H} \cdot$, and the even-electron ion, $w_{4} / d_{4}$, with a sodium or potassium adduct, in which the radical ions are the major components. In the spectrum of protonated/potassiated $\mathrm{dG}_{5}$, a peak corresponding to the loss of a guanine base from the $w_{4} \mathrm{H} \cdot \mathrm{K}$ ion is also observed.

In addition to the fragment ions discussed above, the spectrum following ECD of protonated/potassiated $\mathrm{dG}_{5}$ contains an ion corresponding to the loss of 98.043 Da from the reduced radical parent ion, $[\mathrm{M}+\mathrm{H}+\mathrm{K}]^{+\cdot}$ (see Table 5). However, an ion corresponding to the loss of $98 \mathrm{Da}(98.033)$ is also seen doubly charged, indicating that it might result from collisional activation instead of an electron-induced process. That hypothesis is supported by observation of loss of 98 (98.036) in IRMPD of doubly protonated $\mathrm{dG}_{5}$ (see below). Collisional activation can occur if the cut-off frequencies used in SWIFT isolation are too close to the parent ion frequency.

\section{IRMPD of Polydeoxyguanosine}

The fragmentation pathways observed from IRMPD of doubly protonated, protonated/sodiated, and proton- ated/potassiated $\mathrm{dG}_{5}$, and of doubly protonated $\mathrm{dG}_{7}$, are very similar to those for polydC. The major fragment ions seen in IRMPD of the doubly protonated species are summarized in Table 6 . The most prominent fragment ions correspond to loss of one or two guanine bases. Three consecutive $w / d$ ions are observed in the spectrum of doubly protonated $\mathrm{dG}_{5}$ but only one $w / d$ ion is seen in the spectrum of $\mathrm{dG}_{7}$, possibly because of lower signal-to-noise of the latter parent ion. Base and water losses are observed from ECD of the $w_{4}$ ion for $\mathrm{dG}_{5}$ and from the $w_{6}$ ion for $\mathrm{dG}_{7}$. Also, a loss of $98 \mathrm{Da}$ (98.036) is seen following IRMPD of $\mathrm{dG}_{5}$, as observed in ECD of protonated/potassiated $\mathrm{dG}_{5}$. Possible identifications are loss of $\mathrm{C}_{5} \mathrm{H}_{6} \mathrm{O}_{2}(98.037 \mathrm{Da}), \mathrm{C}_{4} \mathrm{H}_{4} \mathrm{NO}_{2}(98.024$ $\mathrm{Da}), \mathrm{C}_{2} \mathrm{H}_{7} \mathrm{~N}_{2} \mathrm{~K}(98.025 \mathrm{Da})$, and $\mathrm{C}_{3} \mathrm{H}_{4} \mathrm{~N}_{3} \mathrm{O}$ (98.035 Da). However, our present mass accuracy is not sufficient for a unique assignment.

\section{ECD of Doubly Protonated and Protonated/Sodiated Polydeoxyadenosine}

Mass spectra following ECD of doubly protonated and protonated/sodiated $\mathrm{dA}_{6}$ are shown in Figure 6 

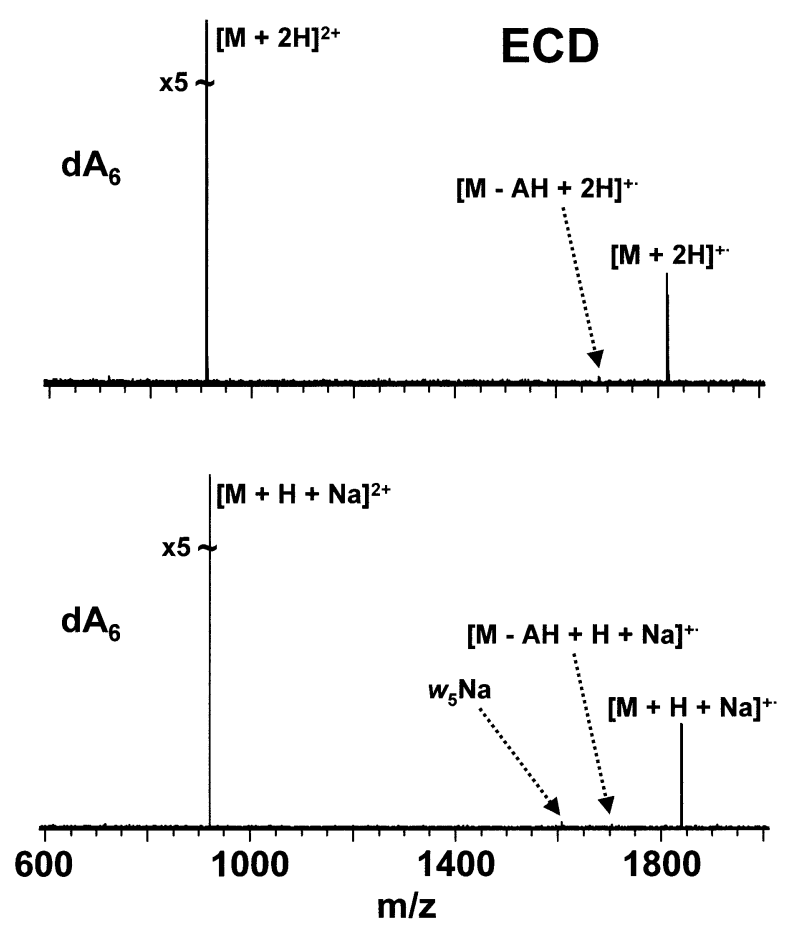

Figure 6. Electron capture dissociation FT-ICR mass spectra of doubly protonated and protonated/sodiated $\mathrm{dA}_{6}$ (50 scans, $30 \mathrm{~s}$ irradiation). Very low abundance fragment ions corresponding to the loss of a neutral adenine base (AH) are seen in both spectra. One $w / d$ "sequence" ion with a sodium adduct is also observed in the ECD spectrum of protonated/sodiated $\mathrm{dA}_{6}$.

and the major fragment ions are presented in Table 7. The parent ion signal-to-noise ratio was too low for observation of ECD products of protonated/potassiated $\mathrm{dA}_{6}$. In contrast to ECD of polydC and polydG, almost no fragmentation is evident. ECD of doubly protonated $\mathrm{dA}_{6}$ yields only one fragment ion, present at very low magnitude, identified as the loss of an adenine base. The relatively large mass error (17 ppm) associated with this ion is probably due to its low abundance. The same ion, but with a sodium adduct, is seen in the spectrum of protonated/sodiated $\mathrm{dA}_{6}$. The latter spectrum also contains one low magnitude $w / d$ peak.

The reduced parent ions, $[\mathrm{M}+2 \mathrm{H}]^{+\cdot}$ and $[\mathrm{M}+\mathrm{H}$ $+\mathrm{Na}]^{+*}$, formed by electron capture by the doubly charged $\mathrm{dA}_{6}$ parent ions, are apparently more stable than the corresponding ions for polydC and polydG. No hydrogen atom ejection to form $[\mathrm{M}+\mathrm{H}]^{+}$and [M $+\mathrm{Na}]^{+}$ions is observed. The ions corresponding to the loss of an adenine base are also radical ions. In contrast, the $w_{5}$ ion observed in the spectrum of protonated/sodiated $\mathrm{dA}_{6}$ is an even-electron ion.

\section{IRMPD of Polydeoxyadenosine}

In contrast to ECD, IRMPD fragmentation pathways for doubly protonated and protonated/sodiated $\mathrm{dA}_{6}$ are very similar to those for polydC and polydG. The major fragment ions observed from IRMPD of doubly protonated $\mathrm{dA}_{6}$ are reported in Table 8 . All possible $w / d$ ions are seen for IRMPD of doubly protonated $\mathrm{dA}_{6}$. As for IRMPD of polydC and polydG, extensive base and water losses are also observed.

\section{Fragmentation of Polydeoxythymidine}

As expected, no molecular ions were observed in the positive ion mode for $\mathrm{dT}_{6}$, due to its low proton affinity $[52,80]$. Consequently, it was not possible to examine its ECD or IRMPD fragmentation patterns.

\section{ECD of Doubly Protonated and Protonated/Sodiated d(GCATGC)}

The results of ECD of the doubly protonated and protonated/sodiated oligodeoxynucleotide, d(GCATGC), are shown in Figure 7 and the major fragment ions are listed in Table 9. This oligonucleotide was chosen because it contains all four deoxynucleotides, and because its sequence is different when read from the $5^{\prime}$ compared to the 3 ' end, making it possible to distinguish between some of the $d$ and $w$ fragment ions $\left(w_{1}\right.$ and $d_{1}, w_{3}$ and $d_{3}, w_{5}$ and $d_{5}$ ). In both mass spectra, the major ECD fragment ion can be identified as a $d_{5}$ ion with a proton or sodium adduct. The $d_{5}$ ion is also observed with addition of water, as seen for the $w / d$ ions of polydC, consistent with the presence of cytosine at the 3' end. As discussed above (see Scheme 1), the "sequence" ion complementary to a $d$ ion should

Table 7. Major fragment ions observed in ECD spectra of doubly protonated and protonated/sodiated $\mathrm{dA}_{6}$. The ion labeled $w$ can also be a $d$ ion. The spectra were internally calibrated

\begin{tabular}{|c|c|c|c|c|}
\hline Sample & Observed $\mathrm{m} / \mathrm{z}$ & Calculated $\mathrm{m} / \mathrm{z}$ & Assignment & Error (ppm) \\
\hline $\mathrm{dA}_{6}$ & $\begin{array}{l}909.2022 \\
1683.321 \\
1818.405\end{array}$ & $\begin{array}{l}909.2022 \\
1683.351 \\
1818.405\end{array}$ & $\begin{array}{l}{[\mathrm{M}+2 \mathrm{H}]^{2+}} \\
{[\mathrm{M}-\mathrm{AH}+2 \mathrm{H}]^{+\cdot}} \\
{[\mathrm{M}+2 \mathrm{H}]^{+\cdot}}\end{array}$ & $\begin{array}{l}\text { calibrant } \\
-17 \\
\text { calibrant }\end{array}$ \\
\hline & $\begin{array}{l}920.1932 \\
1606.277 \\
1705.356 \\
1840.387\end{array}$ & $\begin{array}{l}920.1932 \\
1606.288 \\
1705.332 \\
1840.387\end{array}$ & $\begin{array}{l}{[\mathrm{M}+\mathrm{H}+\mathrm{Na}]^{2+}} \\
w_{5} \mathrm{Na} \\
{[\mathrm{M}-\mathrm{AH}+\mathrm{H}+\mathrm{Na}]^{+\cdot}} \\
{[\mathrm{M}+\mathrm{H}+\mathrm{Na}]^{+\cdot}}\end{array}$ & $\begin{array}{c}\text { calibrant } \\
-6.7 \\
14 \\
\text { calibrant }\end{array}$ \\
\hline
\end{tabular}


Table 8. Major fragment ions observed in IRMPD of doubly protonated $\mathrm{dA}_{6}$. Ions labeled $w$ can also be $d$ ions, and ions labeled $a$ can also be $z$ ions. The spectra were internally calibrated

\begin{tabular}{|c|c|c|c|c|c|}
\hline Sample & Observed $\mathrm{m} / \mathrm{z}$ & Charge & Calculated $\mathrm{m} / \mathrm{z}$ & Assignment & Error (ppm) \\
\hline \multirow[t]{23}{*}{$\mathrm{dA}_{6}$} & 157.0831 & & & & \\
\hline & 216.0874 & 1 & & & \\
\hline & 303.0914 & $6^{*}$ & & $3^{\text {rd }}$ harmonic & \\
\hline & 332.0754 & $?$ & 332.0754 & $w_{1}$ & 0.04 \\
\hline & 412.0411 & $?$ & & & \\
\hline & 454.5998 & $4^{*}$ & & $2^{\text {nd }}$ harmonic & \\
\hline & 492.0681 & $?$ & & & \\
\hline & 636.1298 & 2 & 636.1278 & $w_{4}^{2+}$ & 3.1 \\
\hline & 645.1347 & 1 & 645.1330 & $w_{2}$ & 2.6 \\
\hline & 676.1105 & 2 & & & \\
\hline & 716.1247 & 2 & 716.1241 & $\left(w_{5}-\mathrm{AH}-\mathrm{H}_{2} \mathrm{O}\right)^{2+}$ & 1.0 \\
\hline & 725.0976 & 2 & & & \\
\hline & 765.1432 & 2 & 765.1424 & {$\left[\mathrm{M}-\{\mathrm{AH}\}_{2}-\mathrm{H}_{2} \mathrm{O}+2 \mathrm{H}\right]^{2+}$} & 1.0 \\
\hline & 774.1496 & 2 & 774.1477 & {$\left[\mathrm{M}-\{\mathrm{AH}\}_{2}+2 \mathrm{H}\right]^{2+}$} & 2.4 \\
\hline & 792.6568 & 2 & 792.6566 & $w_{5}^{2+}$ & 0.2 \\
\hline & 805.1266 & 1 & 805.1255 & $\left(w_{3}-\mathrm{AH}-\mathrm{H}_{2} \mathrm{O}\right)$ & 1.4 \\
\hline & 832.6700 & 2 & 832.6697 & {$\left[\mathrm{M}-\mathrm{AH}-\mathrm{H}_{2} \mathrm{O}+2 \mathrm{H}\right]^{2+}$} & 0.4 \\
\hline & 841.6764 & 2 & 841.6750 & {$[\mathrm{M}-\mathrm{AH}+2 \mathrm{H}]^{2+}$} & 1.7 \\
\hline & 908.2022 & 2 & 908.2022 & {$[\mathrm{M}+2 \mathrm{H}]^{2+}$} & calibrant \\
\hline & 958.1965 & 1 & 958.1906 & $w_{3}$ & 6.1 \\
\hline & 1038.232 & 1 & & & \\
\hline & 1118.183 & $?$ & 1118.183 & $\left(w_{4}-\mathrm{AH}-\mathrm{H}_{2} \mathrm{O}\right)$ & -0.2 \\
\hline & 1271.248 & $?$ & 1271.248 & $w_{4}$ & calibrant \\
\hline
\end{tabular}

* = apparent charge

?= only one isotopic peak was observed

be a radical $z$ ion. $\mathrm{A} z_{5} \cdot$ ion with a proton or sodium adduct, respectively, can be identified following ECD of either doubly protonated or protonated/sodiated d(GCATGC).

In addition to the $d$ and $z$ fragment ions, one (or possibly two $w$ ions are observed from ECD of $\mathrm{d}(\mathrm{G}-$ CATGC). The $w_{5}$ fragment is seen as a radical ion containing an additional $\mathrm{H} \cdot$, whereas the possible $w_{4}$ fragment is observed as an even-electron ion. The $w_{5}$ ion is formed by loss of the 5' guanosine unit. As discussed above for ECD of polydG, $\mathrm{H}$ - transfer from guanine bases is probable due to the high tendency of guanine to participate in gas-phase intramolecular hydrogen bonding $[74,78,81]$. Fragments corresponding to the evenelectron ion, $\left(w_{5}-\mathrm{CH}\right)$, are also seen. Cytosine is the $5^{\prime}$ base in the $w_{5}$ ion (i.e., the base closest to the backbone cleavage site). No base loss is observed from the reduced parent ion.

\section{IRMPD of Doubly Protonated and Protonated/ Sodiated d(GCATGC)}

The fragmentation pathways observed for IRMPD of doubly protonated and protonated/sodiated d(GCATGC) are very similar to those established for the homodeoxynucleotides discussed above. The mass spectrum following IRMPD of doubly protonated d(GCATGC) is shown in Figure 8 and the major fragments from IRMPD of both doubly protonated and protonated/ sodiated $\mathrm{d}(\mathrm{GCATGC})$ are listed in Table 10. As for the homodeoxynucleotides, the most prominent fragments correspond to base loss: The loss of one cytosine, one guanine, the loss of both, and an additional loss of water, are seen. The remaining fragment ions are primarily $w$ ions, ( $w$ - base) ions, and ( $w$ - base - water) ions. As for IRMPD of polydC, polydG, and polydA, the sequence coverage is greater in IRMPD compared to ECD, but the spectra are more complex due to extensive base and water loss.

\section{Conclusion}

We have examined the ECD and IRMPD fragmentation pathways of the protonated and protonated/cationized homodeoxynucleotides, polydC, polydG, and polydA, and the heterodeoxynucleotide d(GCATGC). Dissociation of the radical ions produced in ECD is found to follow different pathways than for the photo-induced fragmentation of even-electron ions that occurs in IRMPD. The ECD fragmentation seems to depend on the nucleotide sequence, in which the presence of guanine can result in radical $w / d$ ions and the presence of cytosine or adenine gives even-electron $w / d$ ions. Radical $a / z$-type ions are observed in most polydC spectra, but no even-electron $a / z$ ions are seen in the spectra of polydG. The main ECD fragment in the spectrum of d(GCATGC) corresponds to an even-electron $d$ ion; a z-type ion was also observed. Base loss is a minor fragmentation pathway, except for polydG. Fragment ions corresponding to $w$ or $d$ plus water were 


\section{ECD of d(GCATGC)}
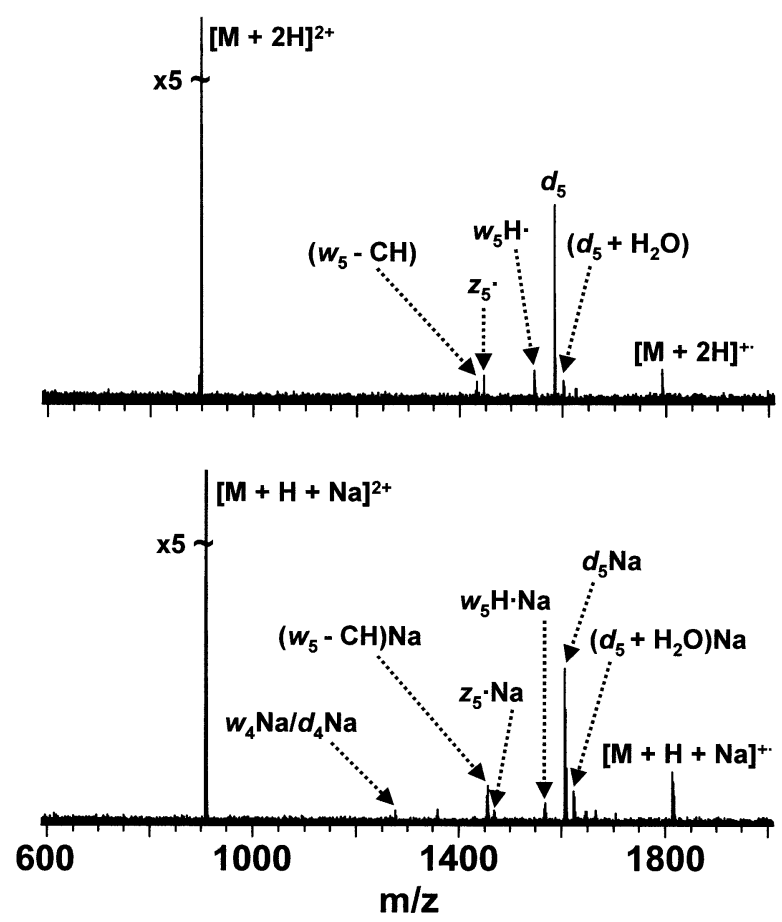

Figure 7. FT-ICR mass spectra following ECD of doubly protonated and protonated/sodiated d(GCATGC) (50 scans, $30 \mathrm{~s}$ irradiation). In both spectra, the major fragment corresponds to a $d$ ion. Radical $z \cdot$ ions are also observed. The $w_{4} / d_{4}$ fragment observed in ECD of protonated/sodiated d(GCATGC) is an even-electron ion whereas the $w_{5} \mathrm{H} \cdot$ fragment is a radical ion. The radical $w_{5} \mathrm{H} \cdot$ ion could be formed by hydrogen atom transfer from the 5 '-guanosine unit, by analogy to the hydrogen transfer observed for polydG (Figures 4 and 5). Peaks corresponding to $\left(d_{5}+\mathrm{H}_{2} \mathrm{O}\right)$ ions are observed both in ECD of doubly protonated and protonated/ sodiated d(GCATGC), and could be due to gas-phase hydrogen bonding between a phosphate oxygen and the free hydroxyl group of the 3'-cytidine nucleoside, by analogy to the observations for polydC (Figures 1 and 2 and Schemes 2 and 3).

also observed in the polydC spectra and in the spectrum of $d(G C A T G C)$. The structure of those ions is not clear.

IRMPD of the same molecules yields fragment ions very similar to those from collision-induced dissociation. The major fragmentation pathway is base loss from the parent ion in all cases. Also, $w$ and ( $a-$ base) "sequence" ions are seen, spanning a larger portion of the sequence than for ECD. However, extensive base and water loss from those ions render the IRMPD spectra more complex.

\section{Acknowledgments}

This work was presented at the 50th ASMS Conference on Mass Spectrometry and Allied Topics, Orlando, Florida, 2002, and was supported by the NSF National High Field FT-ICR Facility (CHE99-09502), Florida State University, the National High Magnetic Field Laboratory in Tallahassee, and the Swedish Foundation for International Cooperation in Research and Higher Education
Table 9. Major fragment ions observed in ECD spectra of doubly protonated and protonated/sodiated d(GCATGC). The spectra were internally calibrated

\begin{tabular}{|c|c|c|c|c|}
\hline Sample & $\begin{array}{c}\text { Observed } \\
\mathrm{m} / \mathrm{z}\end{array}$ & $\begin{array}{c}\text { Calculated } \\
\mathrm{m} / \mathrm{z}\end{array}$ & Assignment & $\begin{array}{l}\text { Error } \\
\text { (ppm) }\end{array}$ \\
\hline \multirow[t]{26}{*}{$\mathrm{d}$ (GCATC } & & & & \\
\hline & 157.0838 & & & \\
\hline & 252.9346 & & & \\
\hline & 298.9180 & & $3^{\text {rd }}$ harmonic & \\
\hline & 448.3405 & & $2^{\text {nd }}$ harmonic & \\
\hline & 896.6801 & 896.6801 & {$[\mathrm{M}+2 \mathrm{H}]^{2+}$} & calibrant \\
\hline & 1432.224 & 1432.224 & $\left(w_{5}-\mathrm{CH}\right)$ & 0.2 \\
\hline & 1446.308 & 1446.298 & $z_{5}$ & 7.2 \\
\hline & 1544.257 & 1544.275 & $w_{5} \mathrm{H} \cdot$ & -11 \\
\hline & 1583.271 & 1583.273 & $d_{5}$ & -1.5 \\
\hline & 1601.276 & 1601.284 & $\left(d_{5}+\mathrm{H}_{2} \mathrm{O}\right)$ & -4.7 \\
\hline & 1793.361 & 1793.361 & {$[\mathrm{M}+2 \mathrm{H}]^{+\cdot}$} & calibrant \\
\hline & 302.5811 & & $3^{\text {rd }}$ harmonic & \\
\hline & 453.8357 & & $2^{\text {nd }}$ harmonic & \\
\hline & 907.6711 & 907.671 & {$[\mathrm{M}+\mathrm{H}+\mathrm{Na}]^{2+}$} & calibrant \\
\hline & 1276.209 & 1276.202 & $w_{4} \mathrm{Na}$ or $d_{4} \mathrm{Na}$ & 5.4 \\
\hline & 1358.148 & & & \\
\hline & 1454.212 & 1454.206 & $\left(w_{5}-\mathrm{CH}\right) \mathrm{Na}$ & 4.5 \\
\hline & 1456.186 & & & \\
\hline & 1468.299 & 1468.280 & $z_{5} \cdot \mathrm{Na}$ & 13 \\
\hline & 1566.244 & 1566.257 & $w_{5} \mathrm{H} \cdot \mathrm{Na}$ & -8.1 \\
\hline & 1605.252 & 1605.255 & $d_{5} \mathrm{Na}$ & -2.1 \\
\hline & 1623.269 & 1623.266 & $\left(d_{5}+\mathrm{H}_{2} \mathrm{O}\right) \mathrm{Na}$ & 2.2 \\
\hline & 1647.266 & & & \\
\hline & 1814.338 & 1814.335 & {$[\mathrm{M}+\mathrm{Na}]^{+}$} & 1.5 \\
\hline & 1815.343 & 1815.343 & {$[\mathrm{M}+\mathrm{H}+\mathrm{Na}]^{+\cdot}$} & calibrant \\
\hline
\end{tabular}

(STINT). RAJO thanks the ARC (grant \# A29930202) for financial support and the University of Melbourne for a sabbatical leave.

\section{References}

1. McLafferty, F. W.; Fridriksson, E. K.; Horn, D. M.; Lewis, M. A.; Zubarev, R. A. Biomolecule Mass Spectrometry. Science 1999, 284, 1289-1290.

\section{IRMPD of d(GCATGC)}

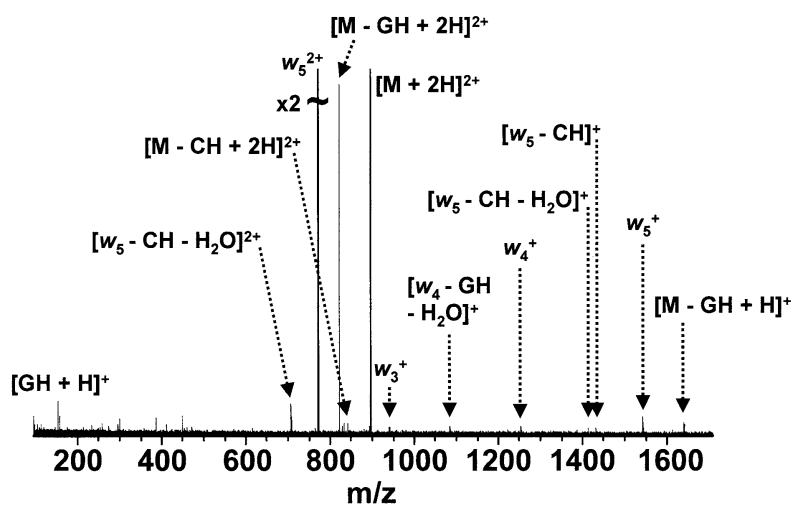

Figure 8. FT-ICR mass spectrum following IRMPD of doubly protonated d(GCATGC) (50 scans, 50 ms irradiation at $2 \mathrm{~W}$ laser power). As for the homodeoxynucleotides (Figure 3, Tables 3, 6, and 8) the major fragments correspond to neutral base loss but extensive backbone fragmentation is also observed. 
Table 10. Major fragment ions observed in IRMPD of doubly protonated and protonated/sodiated d(GCATGC). The spectra were internally calibrated

\begin{tabular}{|c|c|c|c|c|c|}
\hline Sample & Observed $\mathrm{m} / \mathrm{z}$ & Charge & Calculated $\mathrm{m} / \mathrm{z}$ & Assignment & Error (ppm) \\
\hline \multicolumn{6}{|c|}{$\mathrm{d}(\mathrm{GCATGC})$} \\
\hline & 112.0503 & $?$ & 112.0505 & {$[\mathrm{CH}+\mathrm{H}]^{+}$} & -1.6 \\
\hline & 152.0564 & $?$ & 152.0567 & {$[\mathrm{GH}+\mathrm{H}]^{+}$} & -1.8 \\
\hline & 157.0832 & $?$ & & & \\
\hline & 298.9172 & $6^{*}$ & & $3^{\text {rd }}$ harmonic & \\
\hline & 386.0677 & $?$ & & & \\
\hline & 410.5779 & $?$ & & & \\
\hline & 448.3403 & $4^{*}$ & & $2^{\text {nd }}$ harmonic & \\
\hline & 707.6082 & 2 & 707.6101 & $\left(w_{5}-\mathrm{CH}-\mathrm{H}_{2} \mathrm{O}\right)^{2+}$ & -2.7 \\
\hline & 772.1368 & 2 & 772.1370 & $w_{5}^{2+}$ & -0.4 \\
\hline & 821.1553 & 2 & 821.1554 & {$[\mathrm{M}-\mathrm{GH}+2 \mathrm{H}]^{2+}$} & -0.1 \\
\hline & 896.6801 & 2 & 896.6801 & {$[\mathrm{M}+2 \mathrm{H}]^{2+}$} & calibrant \\
\hline & 941.1668 & $?$ & 941.1628 & $w_{3}$ & 4.3 \\
\hline & 1085.158 & 1 & 1085.160 & $\left(w_{4}-\mathrm{GH}-\mathrm{H}_{2} \mathrm{O}\right)$ & -1.8 \\
\hline & 1254.222 & 1 & 1254.220 & $w_{4}$ & 1.5 \\
\hline & 1414.198 & 1 & 1414.213 & $\left(w_{5}-\mathrm{CH}-\mathrm{H}_{2} \mathrm{O}\right)$ & -11 \\
\hline & 1432.246 & $?$ & 1432.224 & $\left(w_{5}-\mathrm{CH}\right)$ & 16 \\
\hline & 1543.267 & 1 & 1543.267 & $w_{5}$ & calibrant \\
\hline & 1641.297 & 1 & 1641.304 & {$[\mathrm{M}-\mathrm{GH}+\mathrm{H}]^{+}$} & -4.2 \\
\hline & 112.0500 & $?$ & 112.0505 & {$[\mathrm{CH}+\mathrm{H}]^{+}$} & -4.3 \\
\hline & 152.0559 & $?$ & 152.0567 & {$[\mathrm{GH}+\mathrm{H}]^{+}$} & -4.9 \\
\hline & 157.0059 & $?$ & & & \\
\hline & 232.0818 & $?$ & & & \\
\hline & 391.5628 & $?$ & & & \\
\hline & 453.8339 & $?$ & & $2^{\text {nd }}$ harmonic & \\
\hline & 718.5991 & 2 & 718.6011 & $\left(w_{5}-\mathrm{CH}-\mathrm{H}_{2} \mathrm{O}\right) \mathrm{Na}^{2+}$ & -2.8 \\
\hline & 727.6046 & 2 & 727.6064 & $\left(w_{5}-\mathrm{CH}\right) \mathrm{Na}^{2+}$ & -2.4 \\
\hline & 767.6186 & 2 & 767.6195 & {$\left[\mathrm{M}-\mathrm{CH}-\mathrm{GH}-\mathrm{H}_{2} \mathrm{O}+\mathrm{H}+\mathrm{Na}\right]^{2+}$} & -1.2 \\
\hline & 776.6216 & 2 & 776.6248 & {$[\mathrm{M}-\mathrm{CH}-\mathrm{GH}+\mathrm{H}+\mathrm{Na}]^{2+}$} & -4.1 \\
\hline & 783.1258 & 2 & 783.1280 & $w_{5} \mathrm{Na}^{2+}$ & -2.8 \\
\hline & 792.6514 & 2 & & & \\
\hline & 832.1448 & 2 & 832.1464 & {$[\mathrm{M}-\mathrm{GH}+\mathrm{H}+\mathrm{Na}]^{2+}$} & 1.9 \\
\hline & 843.1409 & 2 & 843.1442 & {$\left[\mathrm{M}-\mathrm{CH}-\mathrm{H}_{2} \mathrm{O}+\mathrm{H}+\mathrm{Na}\right]^{2+}$} & -3.9 \\
\hline & 852.1461 & 2 & 852.1495 & {$[\mathrm{M}-\mathrm{CH}+\mathrm{H}+\mathrm{Na}]^{2+}$} & -4.0 \\
\hline & 853.1368 & 2 & & & \\
\hline & 907.6711 & 2 & 907.6711 & {$[\mathrm{M}+\mathrm{H}+\mathrm{Na}]^{2+}$} & calibrant \\
\hline & 1107.139 & 1 & 1107.142 & $\left(w_{4}-\mathrm{GH}-\mathrm{H}_{2} \mathrm{O}\right) \mathrm{Na}$ & -2.8 \\
\hline & 1276.206 & 1 & 1276.202 & $w_{4} \mathrm{Na}$ & 2.6 \\
\hline & 1356.164 & 1 & & & \\
\hline & 1436.196 & 1 & 1436.195 & $\left(w_{5}-\mathrm{CH}-\mathrm{H}_{2} \mathrm{O}\right) \mathrm{Na}$ & 0.4 \\
\hline & 1454.207 & 1 & 1454.206 & $\left(w_{5}-\mathrm{CH}\right) \mathrm{Na}$ & 0.9 \\
\hline & 1565.249 & 1 & 1565.249 & $w_{5}$ & calibrant \\
\hline & 1663.287 & 1 & 1663.286 & {$[\mathrm{M}-\mathrm{GH}+\mathrm{Na}]^{+}$} & 0.1 \\
\hline
\end{tabular}

* = apparent charge

$?=$ only one isotopic peak was observed

2. Murray, K. K. DNA Sequencing by Mass Spectrometry. J. Mass Spectrom. 1996, 31, 1203-1215.

3. Nordhoff, E.; Kirpekar, F.; Roepstorff, P. Mass Spectrometry of Nucleic Acids. Mass Spectrom. Rev. 1996, 15, 67-138.

4. Muddiman, D. C.; Smith, R. D. Sequencing and Characterization of Larger Oligonucleotides by Electrospray Ionization Fourier Transform Ion Cyclotron Resonance Mass Spectrometry. Rev. Anal. Chem. 1998, 17, 1-68.

5. McLafferty, F. W. Tandem Mass Spectrometry (Monograph); Wiley: New York, 1983

6. McLuckey, S. A.; Goeringer, D. E. Slow Heating Methods in Tandem Mass Spectrometry. J. Mass Spectrom. 1997, 35, 461474.
7. Woodlin, R. L.; Bomse, D. S.; Beauchamp, J. L. Multiphoton Dissociation of Molecules with Low Power Continuous Wave Infrared Laser Radiation. J. Am. Chem. Soc. 1978, 100, 3248-3250.

8. Little, D. P.; Speir, J. P.; Senko, M. W.; O'Connor, P. B.; McLafferty, F. W. Infrared Multiphoton Dissociation of Large Multiply-Charged Ions for Biomolecule Sequencing. Anal. Chem. 1994, 66, 2809-2815.

9. Price, W. D.; Schnier, P. D.; Williams, E. R. Tandem Mass Spectrometry of Large Biomolecule Ions by Blackbody Infrared Radiative Dissociation. Anal. Chem. 1996, 68, 859-866.

10. Dunbar, R. C.; McMahon, T. B. Activation of Unimolecular Reactions by Ambient Blackbody Radiation. Science 1998, 279, 194-197. 
11. Tsaprailis, G.; Nair, H.; Somogyi, A.; Wysocki, V. H.; Zhong, W.; Futrell, J. H.; Summerfield, S. G.; Gaskell, S. J. Influence of Secondary Structure on the Fragmentation of Protonated Peptides. J. Am. Chem. Soc. 1999, 121, 5142-5154.

12. Bowers, W. D.; Delbert, S.-S.; Hunter, R. L.; McIver, R. T., Jr. Fragmentation of Oligopeptide Ions Using Ultraviolet Laser Radiation and Fourier Transform Mass Spectrometry. J. Am. Chem. Soc. 1984, 106, 7288-7289.

13. Williams, E. R.; Furlong, J. J. P.; McLafferty, F. W. Efficiency of Collisionally-Activated Dissociation and 193-nm Photodissociation of Peptide Ions in Fourier Transform Mass Spectrometry. J. Am. Soc. Mass Spectrom. 1990, 1, 288-294.

14. Zubarev, R. A.; Kelleher, N. L.; McLafferty, F. W. Electron Capture Dissociation of Multiply Charged Protein Cations. A Nonergodic Process. J. Am. Chem. Soc. 1998, 120, 3265-3266.

15. Zubarev, R. A.; Horn, D. M.; Fridriksson, E. K.; Kelleher, N. L.; Kruger, N. A.; Lewis, M. A.; Carpenter, B. K.; McLafferty, F. W. Electron Capture Dissociation for Structural Characterization of Multiply Charged Protein Cations. Anal. Chem. 2000, 72, 563-573.

16. Cerda, B. A.; Horn, D. M.; Breuker, K.; Carpenter, B. K.; McLafferty, F. W. Electron Capture Dissociation of MultiplyCharged Oxygenated Cations. A Nonergodic Process. Eur. Mass Spectrom. 1999, 5, 335-338.

17. Cerda, B. A.; Breuker, K.; Horn, D. M.; McLafferty, F. W. Charge-Radical Site Initiation Versus Coulombic Repulsion for Cleavage of Multiply Charged Ions. Charge Solvation in Poly(alkene glycol) Ions. J. Am. Soc. Mass Spectrom. 2001, 12, 565-570.

18. Olsen, J. V.; Haselmann, K. F.; Nielsen, M. L.; Budnik, B. A.; Nielsen, P. E.; Zubarev, R. A. Comparison of Electron Capture Dissociation and Collisionally Activated Dissociation of Polycations of Peptide Nucleic Acids. Rapid Commun. Mass Spectrom. 2001, 15, 969-974.

19. Zubarev, R. A.; Nielsen, M. L.; Budnik, B. A. Tandem Ionization Mass Spectrometry of Biomolecules. Eur. J. Mass Spectrom. 2000, 6, 235-240.

20. Budnik, B. A.; Haselmann, K. F.; Zubarev, R. A. Electron Detachment Dissociation of Peptide Di-anions: an ElectronHole Recombination Phenomenon. Chem. Phys. Lett. 2000, 342, 299-302.

21. Nielsen, M. L.; Budnik, B. A.; Haselmann, K. F.; Olsen, J. V.; Zubarev, R. A. Intramolecular Hydrogen Atom Transfer in Hydrogen-Deficient Polypeptide Radical Cations. Chem. Phys. Lett. 2000, 330, 558-562.

22. Herron, W. J.; Goeringer, D. E.; McLuckey, S. A. Gas-Phase Electron-Transfer Reactions from Multiply-Charged Anions to Rare-Gas Cations. J. Am. Chem. Soc. 1995, 117, 11555-11562.

23. McLuckey, S. A.; Stephenson, J. L.; O'Hair, R. A. J. Decompositions of Odd- and Even-Electron Anions Derived from Deoxypolyadenylates. J. Am. Soc. Mass Spectrom. 1997, 8, $148-154$.

24. Nielsen, S. B.; Andersen, J. U.; Hvelplund, P.; Jorgenson, T. J. D.; Sorensen, M.; Tomita, S. Triply Charged Bradykinin and Gramicidin Radical Cations: Their Formation and the Selective Enhancement of Charge-Directed Cleavage Processes. Int. J. Mass Spectrom. 2002, 213, 225-235.

25. Chu, I. K.; Rodriguez, C. F.; Lau, T. C.; Hopkinson, A. C.; Siu, K. W. M. Molecular Radical Cations of Oligopeptides. J. Phys. Chem. B 2000, 104, 3393-3397.

26. Zubarev, R. A.; Kruger, N. A.; Fridriksson, E. K.; Lewis, M. A.; Horn, D. M.; Carpenter, B. K.; McLafferty, F. W. Electron Capture Dissociation of Gaseous Multiply-Charged Proteins is Favored at Disulfide Bonds and Other Sites of High Hydrogen Atom Affinity. J. Am. Chem. Soc. 1999, 121, 2857-2862.

27. Kelleher, N. L.; Zubarev, R. A.; Bush, K.; Furie, B.; Furie, B. C.; McLafferty, F. W.; Walsh, C. T. Localization of Labile Post- translational Modifications by Electron Capture Dissociation: The Case of $\gamma$-Carboxyglutamic Acid. Anal. Chem. 1999, 71, $4250-4253$

28. Mirgorodskaya, E.; Roepstorff, P.; Zubarev, R. A. Localization of O-Glycosylation Sites in Peptides by Electron Capture Dissociation in a Fourier Transform Mass Spectrometer. Anal. Chem. 1999, 71, 4431-4436.

29. Stensballe, A.; Norregaard-Jensen, O.; Olsen, J. V.; Haselmann, K. F.; Zubarev, R. A. Electron Capture Dissociation of Singly and Multiply Phosphorylated Peptides. Rapid Commun. Mass Spectrom. 2000, 14, 1793-1800.

30. Shi, S. D.-H.; Hemling, M. E.; Carr, S. A.; Horn, D. M.; Lindh, I.; McLafferty, F. W. Phosphopeptide/Phosphoprotein Mapping by Electron Capture Dissociation Mass Spectrometry. Anal. Chem. 2001, 73, 19-22.

31. Håkansson, K.; Cooper, H. J.; Emmett, M. R.; Costello, C. E.; Marshall, A. G.; Nilsson, C. L. Electron Capture Dissociation and Infrared Multiphoton Dissociation MS/MS of an Nglycosylated Tryptic Peptide Yield Complementary Sequence Information. Anal. Chem. 2001, 73, 4530-4536.

32. Kjeldsen, F.; Haselmann, K.; Budnik, B. A.; Jensen, F.; Zubarev, R. A. Dissociative Capture of Hot Electrons by Polypeptide Polycations: An Efficient Process Accompanied by Secondary Fragmentation. Chem. Phys. Lett. 2002, 356, 201-206.

33. Wee, S.; O'Hair, R. A. J.; McFadyen, W. D. Side-Chain Radical Losses from Radical Cations Allows Distinction of Leucine and Isoleucine Residues in the Isomeric Peptides Gly-XXXArg. Rapid Commun. Mass Spectrom. 2002, 16, 884-890.

34. Steenken, S. Purine-bases, Nucleosides, and NucleotidesAqueous Solution Redox Chemistry and Transformation Reactions of their Radical Cations and e- and $\mathrm{OH}$ Adducts. Chem. Rev. 1989, 89, 503-520.

35. Von Sonntag, C. The Chemistry of Free-radical-mediated DNA Damage. In Physical and Chemical Mechanisms in Molecular Radiation Biology; Glass, W. A.; Varma, M. N., Eds.; Plenum Press: New York, 1991; pp. 287-321.

36. Greenberg, M. M. Investigating Nucleic Acid Damage Processes via Independent Generation of Reactive Intermediates. Chem. Res. Toxicol. 1998, 11, 1235-1248.

37. Boudaiffa, B; Cloutier, P.; Hunting, D.; Sanche, L. Resonant Formation of DNA Strand Breaks by Low-Energy ( 3 to $20 \mathrm{eV}$ ) Electrons. Science 2000, 287, 1658-1660.

38. McLuckey, S. A.; Van Berkel, G. J.; Glish, G. L. Tandem Mass Spectrometry of Small, Multiply-Charged Oligonucleotides. J. Am. Soc. Mass Spectrom. 1992, 3, 60-70.

39. McLuckey, S. A.; Habibi-Goudarzi, S. Decompositions of Multiply-Charged Oligonucleotide Anions. J. Am. Chem. Soc. 1993, 115, 12085-12095.

40. Little, D. P.; Chorush, R. A.; Speir, J. P.; Senko, M. W.; Kelleher, N. L.; McLafferty, F. W. Rapid Sequencing of Oligonucleotides by High-Resolution Mass Spectrometry. J. Am. Chem. Soc. 1994, 116, 4893-4897.

41. Little, D. P.; McLafferty, F. W. Sequencing 50-mer DNAs Using ESI Tandem Mass Spectroscopy and Complementary Fragmentation Methods. J. Am. Chem. Soc. 1995, 117, 67836784.

42. Little, D. P.; Aaserud, D. J.; Valaskovic, G. A.; McLafferty, F. W. Sequence Information from 42-108-mer DNAs (Complete for a 50 mer) by Tandem Mass Spectrometry. J. Am. Chem. Soc. 1996, 118, 9352-9359.

43. Wang, Z.; Wan, K. X.; Ramanathan, R.; Taylor, J. S.; Gross, M. L. Structure and Fragmentation Mechanisms of Isomeric T-Rich Oligodeoxynucleotides: A Comparison of Four Tandem Mass Spectrometric Methods. J. Am. Soc. Mass Spectrom. 1998, 9, 683-691.

44. Gross, J.; Hillenkamp, F.; Wan, K. X.; Gross, M. L. Metastable Decay of Negatively Charged Oligodeoxynucleotides Ana- 
lyzed with Ultraviolet Matrix-Assisted Laser Desorption/ Ionization Post-Source Decay and Deuterium Exchange. J. Am. Soc. Mass Spectrom. 2001, 12, 180-192.

45. Wan, K. X.; Gross, J.; Hillenkamp, F.; Gross, M. L. Fragmentation Mechanisms of Oligodeoxynucleotides Studied by H/D Exchange and Electrospray Ionization Tandem Mass Spectrometry. J. Am. Soc. Mass Spectrom. 2001, 12, 193-205.

46. Wang, Y.; Taylor, J. S.; Gross, M. L. Fragmentation of Electrospray-Produced Oligodeoxynucleotide Ions Adducted to Metal Ions. J. Am. Soc. Mass Spectrom. 2001, 12, 550-556.

47. Wan, K. X.; Gross, M. L. Fragmentation Mechanisms of Oligodeoxynucleotides: Effects of Replacing Phosphates with Methylphosphonates and Thymines with Other Bases in TRich Sequences. J. Am. Soc. Mass Spectrom. 2001, 12, 580-589.

48. Rodgers, M. T.; Campbell, S.; Marzluff, E. M.; Beauchamp, J. L. Site-Specific Protonation Directs Low-Energy Dissociation Pathways of Dinucleotides in the Gas Phase. Int. J. Mass Spectrom. Ion Processes 1995, 148, 1-23.

49. Boschenok, J.; Sheil, M. M. Electrospray Tandem Mass Spectra of Nucleotides. Rapid Commun. Mass Spectrom. 1996, 10, 144149.

50. Ni, J.; Matthews, M. M. A.; McCloskey, J. A. Collision-Induced Dissociation of Polyprotonated Oligonucleotides Produced by Electrospray Ionization. Rapid Commun. Mass Spectrom. 1997, 11, 535-540.

51. Wang, P. P.; Bartlett, M. G.; Martin, L. B. Electrospray Collision-Induced Dissociation Mass Spectra of Positively Charged Oligonucleotides. Rapid Commun. Mass Spectrom. 1997, 11, 846-856.

52. Vrkic, A. K.; O’Hair, R. A. J.; Foote, S.; Reid, G. E. Fragmentation Reactions of All 64 Protonated Trimer Oligodeoxynucleotides and 16 Mixed Base Tetramer Oligodeoxynucleotides via Tandem Mass Spectrometry. Int. J. Mass Spectrom. 2000, 194, 145-164.

53. Weimann, A.; Iannitti-Tito, P.; Sheil, M. M. Characterization of Product Ions in High-Energy Tandem Mass Spectra of Protonated Oligonucleotides Formed by Electrospray Ionization. Int. J. Mass Spectrom. 2000, 194, 269-288.

54. Gross, J.; Leisner, A.; Hillenkamp, F.; Hahner, S.; Karas, M.; Schafer, J.; Lutzenkirchen, F.; Nordhoff, E. Investigations of the Metastable Decay of DNA under Ultraviolet MatrixAssisted Laser Desorption/Ionization Conditions with PostSource-Decay Analysis and Hydrogen/Deuterium Exchange. J. Am. Soc. Mass Spectrom. 1998, 9, 866-878.

55. Håkansson K. unpublished results.

56. Emmett, M. R.; White, F. M.; Hendrickson, C. L.; Shi, S. D.-H.; Marshall, A. G. Application of Micro-Electrospray Liquid Chromatography Techniques to FT-ICR MS to Enable High Sensitivity Biological Analysis. J. Am. Soc. Mass Spectrom. 1998, 9, 333-340.

57. Håkansson, K.; Emmett, M. R.; Hendrickson, C. L.; Marshall, A. G. High Sensitivity Electron Capture Dissociation Tandem FT-ICR Mass Spectrometry of Microelectrosprayed Peptides. Anal. Chem. 2001, 73, 3605-3610.

58. Quinn, J. P.; Emmett, M. R.; Marshall, A. G. A Device for Fabrication of Emitters for Low-Flow Electrospray Ionization. Proceedings of the 46th ASMS Conference on Mass Spectrometry and Allied Topics; Orlando, FL, 1998; pp 1388-1388.

59. Senko, M. W.; Hendrickson, C. L.; Emmett, M. R.; Shi, S. D.-H.; Marshall, A. G. External Accumulation of Ions for Enhanced Electrospray Ionization Fourier Transform Ion Cyclotron Resonance Mass Spectrometry. J. Am. Soc. Mass Spectrom. 1997, 8, 970-976.

60. Marshall, A. G.; Wang, T.-C. L.; Ricca, T. L. Tailored Excitation for Fourier Transform Ion Cyclotron Resonance Mass Spectrometry. J. Am. Chem. Soc. 1985, 107, 7893-7897.
61. Guan, S.; Marshall, A. G. Stored Waveform Inverse Fourier Transform (SWIFT) Ion Excitation in Trapped-Ion Mass Spectrometry: Theory and Applications. Int. J. Mass Spectrom. Ion Processes 1996, 157/158, 5-37.

62. Ledford, E. B., Jr.; Rempel, D. L.; Gross, M. L. Space Charge Effects in Fourier Transform Mass Spectrometry Mass Calibration. Anal. Chem. 1984, 56, 2744-2748.

63. Shi, S. D.-H.; Drader, J. J.; Freitas, M. A.; Hendrickson, C. L.; Marshall, A. G. Comparison and Interconversion of the Two Most Common Frequency-to-Mass Calibration Functions for Fourier Transform Ion Cyclotron Resonance Mass Spectrometry. Int. J. Mass Spectrom. 2000, 195/196, 591-598.

64. Rakvin, B.; Herak, J. N. ESR Study of the Oxidation-Reduction Products in an Irradiated $\alpha$-Glycerol Phosphate Single Crystal. J. Chem. Phys. 1981, 74, 2091-2093.

65. Celalyan-Berthier, A.; Berclaz, T.; Geoffroy, M. Radiation Damage in a Phosphated Sugar. J. Chem. Soc. Faraday Trans. 1 1987, 83, 401-409.

66. Nelson, D. J.; Symons, M. C. R.; Wyatt, J. L. Electron Paramagnetic Resonance Studies of Irradiated D-Glucose-6-Phosphate Ions: Relevance to DNA. J. Chem. Soc. Faraday Trans. 1993, 89, 1955-1958.

67. Bungum, B.; Hole, E. O.; Sagstuen, E.; Lindgren, M. Electron Paramagnetic Resonance of X-Irradiated Sodium and Potassium Salts of Glucose-1-Phosphate-Identification of $\mathrm{PO}_{3}{ }^{2-}$ Radicals at Room Temperature. Radiat. Res. 1994, 139, 194-202.

68. Sanderud, A.; Sagstuen, E. EPR Study of X-Irradiated Hydroxyalkyl Phosphate Esters: Phosphate Radical Formation in Polycrystalline Glucose Phosphate, Ribose Phosphate, and Glycerol Phosphate Salts at 77 and 295 K. J. Chem. Soc. Faraday Trans. 1996, 92, 995-999.

69. Krilov, D.; Herak, J. N. ESR Evidence for the RadiationInduced Breakage of the Sugar-Phosphate Bonds in Nucleotides: Single Crystal of Deoxycytidine 5'-Monophosphate. Biochem. Biophys. Acta 1974, 366, 396-401.

70. Krilov, D.; Velenik, A.; Herak, J. N. ESR Study of RadiationInduced Radicals in the Sugar-Phosphate Region of Nucleotides. III. The Alkoxy Radical in Deoxycytidine 5'-Phosphate. J. Chem. Phys. 1978, 69, 2420-2423.

71. Becker, D.; Sevilla, M. D. The Chemical Consequences of Radiation Damage to DNA. Adv. Radiat. Biol. 1993, 17, 121-180.

72. Steenken, S.; Goldbergerova, L. Photoionization of Organic Phosphates by $193 \mathrm{~nm}$ Laser Light in Aqueous Solution: Rapid Intramolecular H-Transfer to the Primarily Formed Phosphate Radical. A Model for Ionization-Induced Chain-Breakage in DNA? J. Am. Chem. Soc. 1998, 120, 3928-3934.

73. Phillips, D. R.; McCloskey, J. A. A Comprehensive Study of the Low Energy Collision-Induced Dissociation of Dinucleoside Monophosphates. Int. J. Mass Spectrom. Ion Processes 1993, 128, $61-82$.

74. Robinson, J. M.; Greig, M. J.; Griffey, R. H.; Mohan, V.; Laude, D. A. Hydrogen-Deuterium Exchange of Nucleotides in the Gas Phase. Anal. Chem. 1998, 70, 3566-3571.

75. Perreault, D. M.; Anslyn, E. V. Unifying the Current Data on the Mechanism of Cleavage-Transesterification of RNA. Angew. Chem. Int. Ed. Engl. 1997, 36, 432-450.

76. Oivanen, M.; Kuusela, S.; Lonnberg, H. Kinetics and Mechanisms for the Cleavage and Isomerization of the Phosphodiester Bonds of RNA by Brönsted Acids and Bases. Chem. Rev. 1998, 98, 961-990.

77. Lopez, X.; Schaefer, M.; Dejaegere, A.; Karplus, M. Theoretical Evaluation of $\mathrm{pKa}$ in Phosphoranes: Implications for Phosphate Ester Hydrolysis. J. Am. Chem. Soc. 2002, 124, 50105018. 
78. Freitas, M. A.; Shi, S. D. H.; Hendrickson, C. L.; Marshall, A. G. Gas-Phase RNA and DNA Ions. 1. H/D Exchange of the [M $\mathrm{H}]^{-}$Anions of Nucleoside 5'-Monophosphates (GMP, dGMP, AMP, dAMP, CMP, dCMP, UMP, dTMP), Ribose 5-Monophosphate, and 2'-Deoxyribose 5-Monophosphate with $\mathrm{D}_{2} \mathrm{O}$ and $\mathrm{D}_{2}$ S. J. Am. Chem. Soc. 1998, 120, 10187-10193.

79. Green-Church, K. B.; Limbach, P. A.; Freitas, M. A.; Marshall, A. G. Gas-Phase Hydrogen/Deuterium Exchange of Positively Charged Mononucleotides by Use of Fourier-Transform Ion Cyclotron Resonance Mass Spectrometry. J. Am. Soc. Mass Spectrom. 2001, 12, 268-277.
80. Green-Church, K. B.; Limbach, P. A. Mononucleotide GasPhase Proton Affinities as Determined by the Kinetic Method. J. Am. Soc. Mass Spectrom. 2000, 11, 24-32.

81. Griffey, R. H.; Greig, M. J.; Robinson, J. M.; Laude, D. A. Gas-Phase Hydrogen-Deuterium Exchange in Phosphorothioate d(GTCAG) and d(TCGAT). Rapid Commun. Mass Spectrom. 1999, 13, 113-117.

82. Sevilla, M. D.; Becker, D.; Yan, M. Y.; Summerfield, S. R. Relative Abundances of Primary Ion Radicals in Gamma-Irradiated DNA-Cytosine Versus Thymine Anions and Guanine Versus Adenine Cations. J. Phys. Chem. 1991, 95, 3409-3415. 